\title{
An Integrated Model for Dimensioning the Reserve Fleet based on the Maintenance Policy
}

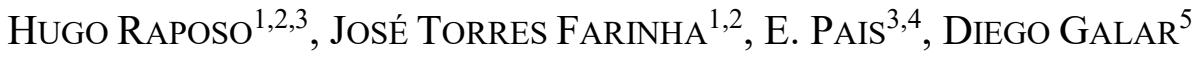 \\ hugo.raposo@isec.pt, torres.farinha@dem.uc.pt, edmundopais@gmail.com,diego.galar@ltu.se \\ ${ }^{1}$ CEMMPRE - Centre for Mechanical Engineering, Materials and Processes, Coimbra, PORTUGAL \\ ${ }^{2}$ ISEC - Instituto Superior de Engenharia de Coimbra, PORTUGAL \\ ${ }^{3}$ ULHT - Universidade Lusófona de Humanidades e Tecnologias, PORTUGAL \\ ${ }^{4}$ CISE - Electromechatronic Systems Research Centre, University Beira Interior, Covilhã, \\ PORTUGAL \\ ${ }^{5}$ LTU - Luleå University of Technology, SWEDEN
}

\begin{abstract}
Usually, the Reserve Fleet, or Spare Fleet, of passenger urban buses, is based on indicators used in some international relevant companies and extrapolated for many others, almost as a dogma. However, it must be taken into consideration pragmatic variables intrinsic to the buses namely their maintenance and in a more pragmatic approach, indexing their availability and by consequence the reserve fleet indexed to the maintenance policy used in each company.

The paper discusses these subjects and presents a global model that integrates the maintenance planning policy, based on a condition monitoring model, maintenance Key Maintenance Indicators (KPI), and an economic life cycle model.

The paper presents some results based both in theoretical considerations and also in real data from an urban fleet of a European Country.
\end{abstract}

Keywords: Econometric models; Maintenance policies; Time series; Oil analysis; Diesel engines.

Received: May 1, 2020. Revised: November 5, 2020. Accepted: December 20, 2020. Published: January 7, 2021.

\section{Introduction}

Nowadays, the public transport users are increasingly demanding about the quality of services provided, maintenance stands out as a competitiveness factor. The Life Cycle Cost (LCC) of a bus in urban transport is intrinsically dependent on the quality of the management of its maintenance, which is reflected on reliability and availability. There are still other aspects that need to be considered, such as fuel costs, inflation and real discount rates. The bus replacement time or renewal may be assessed by methods such as "economic life" or "useful life". These models are strongly discussed throughout the paper using data from a city bus company for its validation. The paper also refers to an approach about the conditioning maintenance based on oil analysis of urban buses engines, in which the evolution of its degradation is monitored in order to evaluate the potential impact of a conditioning maintenance policy on the reserve fleet. This approach should usually, lead to enlarge the maintenance intervals when compared to the systematic ones that would be used by default. As a result, the maintenance costs are reduced, and economic and useful lives are increased. The combination of the foregoing aspects has implications for the dimensioning of the reserve fleet, as demonstrated throughout the paper, which implies that maintenance, and in particular oil analysis should be considered within a strategic perspective in the companies of road passengers transport. The determination of the time considered the most rational for the replacement of a passenger bus when framed in a fleet, has implications in determining the size of the respective reserve fleet implying to equation the economic variables, that can be divided into endogenous and exogenous: the first ones relates to operating and maintenance costs as well as the assets devaluation; the second ones to the imponderables of the market such as inflation and real discount rates, as well as energy costs, namely the fuel. The paper also presents an overview of the econometric models for replacement through a global model, with emphasis on availability and maintenance costs. The paper also discusses the relationships between some maintenance Key Performance Indicators (KPI), specifically the MTTR (Mean Time Between Repairs), the Mean Time Between Failures (MTBF), the Availability (D), and the Reserve fleet. The Return On Investment (ROI) is a financial indicator to evaluate the financial performance of the equipment that is used as a "bridge" between the maintenance and the financial management fields, showing the time when the equipment begins to generate profits to the company. It also analyses models to evaluate the influence of these variables on the withdrawal time and in the reserve fleet size, using the oil analysis as 
an example. The paper also presents a framework synthesis of the preceding variables, through a global model, demonstrating its relevance to the analysis of the reserve fleet size and the withdrawal buses time. Finally, a Model Integrated Reserve Fleet Assessment (MIFRA) is presented, which can be integrated into a maintenance information system, through the addition of new conditioning and predictive maintenance modules, as well as the mentioned replacement models, thereby extending the potential of the existing information systems to global equipment lifecycle management perspective.

\section{State of the Art}

The current competitive environment increasingly demands companies for a constant improvement in all aspects. Thus, in order to obtain a leading position companies, aim to maintain their operating standards above the competitors.

Consequently, business development has led to a significant advance in terms of quality and productivity in most of the various industrial sectors. In the last three hundred years humanity has evolved greatly, production has increased, services have expanded, causing true industrial revolutions.

It is increasingly recognized that improving the quality of products and services is an extremely important issue for the organization's competitiveness. For those who produce or provide services, quality means greater customer or user satisfaction, increased competitiveness and success, as well as return on the assets invested.

It is under this perspective that the identification of the optimum time to replace a physical asset can be a determining element in the organization's competitiveness, through the costs reduction that can result from it, what can be indexed to the maintenance policy used.

Equipment replacement is a broad concept that ranges from the selection of similar assets, to the evaluation of assets that have different performance to the same function, such the ones with more functions and that are more efficient. Replacement decisions are of critical importance for organizations in any sector, often implying the survival of the organizations themselves.

There are several non-exclusive reasons that make equipment replacement economical. Deterioration is one of the causes that is revealed by excessive operating and maintenance costs. There are situations in which the change of a current operation an equipment loses the capacity to operate efficiently, that is, the equipment becomes inadequate.

The efficient use of physical assets is one of the main objectives in the management of organizations, namely public or private. These organizations are subject to a large set of mandatory rules, including the exigence of the players that use the facilities (employees, users, service providers and visitors). The set of ISO 5500X standards appears to respond to this need to better manage the life cycle of the organization's physical assets, ensuring the level of competitiveness, without compromising the level of excellence of the products / services offered. The ISO 55001 standard proposes a methodology to manage assets in accordance with the Organization's strategic objectives, supporting decisions on acquisition, replacement and or their disposal; this is in line with practices aimed at the environmental, social and economic sustainability of the equipment and of the company itself, ([33], [78], [79], [80] and [90]).

According [32], the mechanization associated with the Industrial Revolution of the $19^{\text {th }}$ Century highlighted the need to regularly repair machines; however, these interventions were left to the operators themselves. Only after World War I the industry was pressured to reach minimum production standards, leading to the establishment of specialized teams to repair the damages in the shortest possible time. These teams, however, were limited to corrective maintenance, remaining dependent on production.

Unplanned maintenance corresponds to a policy in which interventions seek to recover the equipment to reach its normal operating state after the failure has occurred.

Unplanned maintenance is the simplest and most primary form of intervention being a management option, usually very expensive when economically evaluated from the point of view of the system's operation [42]:

- Low utilization and reduced equipment life, consequently impacting the productivity of the resources of production, regardless of whether they are products or services;

- The stop for maintenance at random, and often inopportune moments, with very high indirect costs.

In the 1930s, mass production in industrialized countries and the international situation that preceded World War II, forced them to produce more and more. The companies then started to worry, not only in correcting the failures, but also in preventing their appearance, which widened the scope of maintenance that also started to act on the prevention of anomalies.

On systematic planned maintenance, interventions follow a program that is intended to be executed periodically, with intervals being measured according a certain time unit or in another parameter of use that translates the operation of the equipment, also called "systematic preventive maintenance". 
Systematic planned maintenance or preventive planned maintenance consists of a methodology for the prevention of defects that are likely to cause the stoppage or low performance of production equipment or systems [25]. It is associated with traditional maintenance management systems, currently supported by computer media. They do not prevent faults from occurring, but they do allow shorten downtime. This prevention is usually developed based on statistical studies, equipment status, location or operating conditions and data provided by the manufacturer (optimal operating conditions, lubrication points and frequency, etc.). The indexes usually extracted from the database are MTBF and MTTR [35]. Although the degradation processes of the equipment are different from case to case, and the causes of failures themselves are also different, these indices are especially useful, particularly in situations where the standard deviation of the times between occurrences is reduced. Among the advantages that are associated with this maintenance profile, the following can be enumerated:

- Decrease in the total number of corrective interventions, consequently reducing the associated costs;

- Strong reduction in the number of breakdowns occurring at inopportune moments, such as, for example, night periods, weekends and critical periods of production;

- Significant increase in utilization / availability ratios.

The expansion of commercial aviation, starting in the 1940s, brought new challenges to maintenance. On the one hand it compelled to develop preventive methods, since the repair of breakdowns during the flight is rarely possible, and on the other hand it accentuated the problem of the safety of people and goods.

The advent of computers has led many companies to implement systematic preventive maintenance strategies. This approach still dominant today, typically uses maintenance planning programs to control calendar-based maintenance activities to trigger work orders automatically.

[19], stats that the designation of conditioned maintenance appeared in the 70-80's to designate a new approach to preventive maintenance, based on knowledge of the real state of the machines, from the implementation of a condition control system.

It is a matter of deciding the opportunities for interventions in equipment based on knowledge of its real state, instead of carrying out planned maintenance work at fixed intervals, as is the case with systematic maintenance, they are carried at variable intervals determined by the state of the equipment. Conditioned maintenance focus on equipment considered individually, replacing revisions at fixed intervals with inspections at fixed intervals. The economic benefits of conditioned maintenance arise from gains from reduced production losses, due to increased equipment availability and gains from reduced maintenance costs, however this methodology needs to consider the additional costs of data collection, either manually or automatically.

There are several techniques for controlling the condition of machines and equipment with application in maintenance, of which the following stand out: vibration analysis, thermography, analysis of performance parameters, visual inspection, ultrasonic measurements, and analysis of service lubricants.

In the mid-1980's, technological advances in instrumentation and the growing of the personal computers enabled the ability to predict problems in machines by measuring their condition using vibration, temperature and ultrasound sensors, this technology is often referred to as predictive condition maintenance. Another more advanced maintenance strategy called Proactive Maintenance allows to prolong the failure cycles of the machines by systematically removing the sources of failure.

According to [65], one of the main objectives of modern maintenance management is to maximize the availability of equipment, while lowering the cost and raising the quality, maintaining safety and preserving the environment.

Around the year 2000, industrial processes gained new challenges in terms of productivity and quality with the trend of globalization of the economy. The large investment in fixed assets, together with the increase in costs, begins with a process of high expectations regarding maintenance. Such expectations are found in the functions and results of the maintenance, in the new interpretations of the processes of equipment failures and in the new techniques of analysis and implementation of the maintenance, thus creating alternatives that can maximize the useful life of the physical assets. Since 2000, maintenance has been part of integrated management systems, considering the improvement of maintenance and maintenance engineering, using advanced technology of interconnected systems, optimized investments, and intelligent products. According to [68], maintenance has evolved more than other management functions, due to the increase in the number, complexity and diversity of facilities, equipment and production systems.

If before the maintenance objective was to restore the original conditions of a certain equipment or system, according to [32], currently maintenance guarantees the availability of equipment and systems 
in order to meet the production process at an appropriate cost, with safety, reliability and preservation of the environment.

The vision presented by [32], in which he states that "with the evolution of the various maintenance concepts, and with the development of new approaches and methodologies applied to other management aspects, namely in the area of quality and production, the activity maintenance started to mesh, to include and adapt these new concepts", being of high importance for organizations.

For [101], many years after the appearance of the first information system for maintenance management, some basic problems remain, now with new frontiers. The concept started with simple maintenance, went through therotechnology [45], total productive maintenance, therology [31], until reaching maintenance centered on reliability [69]. Therology is defined as the combined use of operational research, information management and engineering techniques, with the aim of monitoring the equipment's life cycle. It includes the definition of the specifications regarding its acquisition, installation, and reception, as well as the management and control of its maintenance, modification and replacement and, also, its monitoring in service.

The maintenance of passenger transport buses is a strategic activity to guarantee the fulfilment of its life cycle, which implies combining management, technical and economic actions, in order to obtain a high availability at rational costs, ( [6], [9], [10], [14] [48] and [54]).

[6] report that poor maintenance management contributes to a significant financial cost. The theoretical basis of this subject shows that the life cycle cost (LCC) of an asset represents the sum of all the capital spent to support the asset, from design and manufacture, through the operation until the end of its useful life (CAPEx + OPEx - Capital expenses + Operating expenses), [9].

The LCC of an asset corresponds to the sum of all capital spent on supporting that asset from its conception and manufacture, through the operation until the end of its useful life [10].

The LCC of an asset can be significantly higher than the value of the initial investment and, in many cases, is defined right at the project stage [9].

[14] goes further and reinforces this idea, pointing out that 70 to $90 \%$ of these total LCC costs are defined in the design and manufacture phase.

The initial investment costs are usually the most used as a primary criterion, and sometimes, the only one in the purchase decision. Despite the obvious longterm benefits of LCC analysis, its adoption has been relatively slow. Possible reasons for this include the lack of standard or formal guidelines and the absence of reliable previous data. The number of cross-case studies in the field of LCC is extremely low and most of them are limited to a single industry [54].

[48] provide an overview of the use of the LCC and its feasibility of implementation, through a summary of the work and its application.

Life cycle cost analysis is a forecast of the future and, as such, different methods are generally used to make cost estimates, such as Activity-Based Costing (ABC), ([29] and [30]).

To support the LCC analysis, there are related standards and documents, such as those referred to in ([11], [12], and [46]. The asset management standards that followed [12], that is, [46] (ISO 55000:2014, ISO55001:2014 and ISO55002:2018), are good sources as guidelines for the management of assets and can be applied in any sector.

[10] illustrates how, throughout the life cycle of an equipment, the mastery of concepts and some financial calculation tools become essential for maintenance managers and organizations.

However, the systematic study in this area remains underdeveloped, with the need to apply and create new models of equipment management that can bring added value to companies, in order to improve their productivity and quality of service, taking into account the aspect environmental sustainability, including standards for quality management, environment, safety, maintenance and energy, [32]. It is also noted that many companies keep equipment in operation, even when its operation is no longer economically viable, because it does not follow its economic cycle, [32], which has exogenous implications, namely in the size of the reserve fleet, in the case of bus fleets.

[112], traditional production systems are built on the principle of economies of scale. This author also illustrates an equipment replacement problem, in the context of Lean Thinking.

[114] refer to technological change as a motivator for the replacement of equipment. In scientific references, it is commonly assumed that technology develops continuously according to a well-defined function.

[73] demonstrate that combining continuous and discrete models, over time the equipment replacement period is shorter when the incorporated technology is longer.

According to [8], "the valuation of an asset is established by the expected future benefits of the cash flows referred to the present value, through a discount rate that reflects the risk of the decision". Consequently, the methods that consider the value of money over time are the most suitable.

According to [23], the Equivalent Uniform Annual Cost method is adequate in the analysis of the company's operational activities, with investments 
that can be repeated. In addition, the standardization of investment results to equivalent annual values makes the analysis of these results easier for decision making. The use of this method aims to determine in which year the lowest equivalent annual cost occurs, which indicates the best period for replacing the technical asset [23].

The calculation of the equivalent annual cost is due to the use of the Capital Recovery Factor and it is through it that two or more investment opportunities can be compared and determine the ideal time for the replacement of the equipment, taking into account information such as: investment or acquisition value, resale value or residual value at the end of each year, operating costs and capital cost or the attractive minimum rate [107].

The problem of determining the economic life of equipment for replacement purposes is seen in four types of situations [67]:

i. When the property is already inadequate for the activity;

ii. When the asset has reached its useful life limit;

iii. When the good is already obsolete, due to technological advancement;

iv. When more efficient methods prove to be more economical.

At a certain point in the asset's life cycle, it's important to assess whether is of interest to keep it in operation or to replace it. For this purpose, the following aspects must be considered [32] and [33]:

i. Availability of new technologies;

ii. Compliance with safety or other mandatory standards;

iii. Availability of spare parts;

iv. Obsolescence that may limit its use.

After listing the aspects related to the last point of the equipment's life cycle, it is important to characterize some calculation methods to determine the appropriate time for its replacement. For this purpose, it is necessary to consider several variables, such as: acquisition value, assignment amount, operating costs, maintenance costs, operating costs, inflation rate, and capitalization rate.

The values of most of the preceding variables are obtained through history, except for the assignment value, in this case, the market value for each specific piece of equipment will have to be obtained, which may prove difficult for many goods. Alternatively, several types of devaluation can be simulated, such as the following ([32], [33] and [76]):

- Linear depreciation method - the decline in the value of the equipment is constant over the years;

- Digit sum method - annual devaluation is non-linear; $\circ$ Exponential method - the annual depreciation charge is decreasing over the life of the equipment.

Another method usually used is the "useful life" method, which defines that it ends when its maintenance costs exceed the maintenance costs plus the amortization of the capital of an equivalent new equipment. According to [32], there are several methods for determining the economic cycle of equipment replacement. The most common are the following:

- Uniform Annual Income Method (MRAU);

- Average Total Cost Minimization Method (MCMT);

- MCMT method with reduced present value (MCMT-RVP).

[34] illustrate the efficient use of fixed assets as one of the main objectives in the management of companies in urban passenger transport sector.

In companies of road transport sector, the efficient use of assets is linked to a well-structured fleet assessment and replacement policy. Some cases of fleet replacement applied to the city bus segment are reported in ([13], [28], [39], [47], [84], [88], [89], [91], [92], [93], [94], [95], [96], [97], [98], [99], [111] and [118]).

[13] proposes a policy for optimal replacement intervals for programming technical systems based only on the maintenance cost parameter: a system is replaced by a new one as soon as the maintenance cost within a replacement cycle reaches or exceeds one certain level.

[39] studied and described an industrial application of an Energy Law Process (PLP - Power Law Process) for bus engine failures and a theoretical replacement model.

[84] adopted a model for a problem of replacing the transit fleet with various types of buses. However, many costs were highly simplified or were not based on real data, and the variability in vehicle characteristics, uses and market fluctuations have not been studied. The cost of replacing, remanufacturing and rehabilitating a bus has been a focus of research by [47], as well as the optimal allocation proposed by the Federal Transit Administration (FTA). Other lines of investigation have focused on statistical analysis of fleet data and on the relationships between age, use and costs, [28]. [88] present a new approach to economic models for determining the most suitable time for replacing buses in a company's urban fleet. The presented study allows the assessment of the equipment's life cycle by the managers and, obviously, it is a decision support tool. It was shown in the study that there is a variation of the ideal moment for the replacement of 
a vehicle in a fleet, given by the analyses carried out by the Uniform Annual Income model.

A numerical solution is proposed and illustrated by [99], using data from a given fleet, they considered a two-cycle replacement model, with decision variables based on the age of replacement of the current fleet, where the size of the new fleet is considered, the optimal values for the decision variables can be found by minimizing the total cost discounted per unit of time or the value of the equivalent income.

Many studies consider reliability parameters and maintenance costs to help assess more rational replacement decisions, for example: ([88], [89], [91], [92], [93], [94], [95], [96], [97], [98], [99], [111] and [118]).

[22] present a proposal for a generic model of stochastic process based on neural networks, called Neuronal Stochastic Process (PEN), which can be applied to problems, involving phenomena of stochastic behavior and or with periodic characteristics. Through the PEN neural networks, the behavior of the historical series of these phenomena is modeled without needing a priori information about the series, generating synthetic time series, equally adaptable to the historical series. Some cases of use of neural networks and stochastic models are reported in ([3], [7], [22], [38], [43], [44], [55], [62], [71], [109] and [117]).

There are other tools that can contribute to the development of a new model of vehicle replacement optimization, such as, Fuzzy Logic and the Support Vector Machine (SVM): ([21], [24], [27], [86], [106] and [115]).

Regarding predictive maintenance, and specifically the analysis of oils, some mathematical models and concepts were used, which are referenced by the following authors: ([4], [5], [17], [19], [32], [33], [40], [56], [57], [58], [66], [88], [89], [91], [92], [93], [94], [95], [96], [97], [98], [99] and [116]).

[5] justifies the utility and necessity of mathematics in engineering, analysing the main mathematics courses in engineering courses, reflecting on the real or desirable connection between mathematics and engineering courses. Finally, it points out the interest in carrying out statistical analyses and details these analyses with some examples.

Predictive maintenance is often referred to as condition monitoring or condition-based maintenance, that is, it evaluates the real state of the equipment using specific equipment, with the aim of adjusting the preventive maintenance planning, detecting possible failures early, avoiding the emergence of complex problems, and provide decision-making based on real data.

The standard [74] defines predictive maintenance as "conditioned maintenance carried out in accordance with the extrapolated forecasts of the analysis and evaluation of significant equipment degradation parameters".

[66] defines predictive maintenance as regular monitoring of the current state of mechanical conditions, efficiency of operation, and other indicators, in order to provide data that ensure the maximum interval between repairs and that minimize the number and cost of unscheduled stops. [17] presents predictive maintenance as an approach that compares the trend of measurements of the analysed physical parameters (vibration, pressure, current, temperature, ...) with the limits established for these parameters, in order to detect, analyse and correct problems before that lead to equipment failure.

According to [53] the adoption of predictive maintenance details the physical items for control and maintenance of the quality of the final product that is generated in the equipment. [104], on other hand, defines that predictive maintenance is the one that indicates the real operating conditions of the machines based on data that inform about their wear or degradation process.

According to [77], predictive maintenance corresponds to interventions that ensure the desired quality of service, based on the systematic application of analysis techniques, using centralized supervision or sampling methods to minimize preventive maintenance and reduce corrective maintenance.

These points of view and the definitions of predictive maintenance mentioned above reinforce the importance of this type of maintenance in the life cycles of the equipment, thus allowing better monitoring and better management of the equipment.

Regarding oil analysis, [57]show the results of a fleet test, whose main objective was to measure the influence of low viscosity oils (LVO - Low Viscosity Oils) on the fuel consumption and $\mathrm{CO} 2$ emissions of city buses. To perform this test, 39 city buses were used, classified in groups according to the viscosity of the engine oil they use; in this study the vehicles covered $60,000 \mathrm{~km}$, which correspond to two oil change intervals, these authors have over the years published articles on bus fleets.

[87] and [93] present a study referring to urban bus engine oils, in which the evolution of its degradation is monitored, with the aim of evaluating the potential impact of a conditioned / predictive maintenance policy on management companies related with fleets of city buses. Through the analyses obtained in the lubricants in service, precious information about the operating conditions of the engines can be collected, which are indispensable for the optimization of their operation. Based on this information it is possible to 
assess the condition of the engines, determine the most appropriate moment for their replacement and, additionally obtain a diagnosis in the condition of the equipment and its evolution. In this study, the time intervals corresponding to a required level of reliability were determined, consequently obtaining more suitable intervals for planned maintenance interventions. With this monitoring of the degradation of lubricating oils, the safety of the operation of buses is further increased, costs are reduced, and energy efficiency is improved., in the study of the influence of a conditioned / predictive maintenance policy on the reserve fleet, the KPIs considered most suitable for this purpose were used. [20] read: "the term used for maintenance performance indicators in an Industry is the acronym KPI". KPIs can measure different performances, ranging from the time of equipment failure to the production process. Currently, software programs installed in many companies can offer a few dozen KPIs, but you need to pay attention to those that really add value. In this sense, it is important to select the most appropriate to achieve the desired objectives.

According to [20], the standard [75], "Maintenance - Maintenance Performance Indicators (KPI)", in its introduction, “... establishes maintenance performance indicators, to support management in order to achieve excellence in maintenance and use of fixed assets in a competitive manner. Most of these indicators apply to all industrial facilities and services (equipment, buildings, infrastructure, transport, among others)".

Regarding the maintenance performance indicators that are used to measure and evaluate the management of equipment and maintenance, the following authors refer: ([35], [37], [49], [50], [63], [70], [72], [81], [105], [108] [110], and [114]).The definition of an indicator must include at least the following characteristics: name, type (economic, technical, organizational, etc.), precise definition and data necessary for its calculation, by definition, it refers to the mathematical formula that relates the name of the indicator with the data necessary for its calculation. The maintenance indicators must be evaluated for the objects under analysis, in each time interval, and the analysis of the results can focus on the absolute values of that indicator or on the trend it demonstrates [63].

Along with the definition of the indicators, a hierarchy must be established for them.

Used correctly, performance indicators should highlight opportunities for improvement in companies and subsequently be subject to more indepth analysis to discover the reason for their value. They can even point directly to the solution of the problem [114].
Unlike the case of other functions, such as production, the measurement of maintenance performance is still very incipient, many tools and techniques have been developed and applied in other fields and areas, but the application of these tools to the maintenance function still needs to be increased, although their correct use can help more efficient maintenance management, given their great technical growth and technological complexity. [82]. To know what to measure it is necessary to outline the entire maintenance process within the organization and all its interrelationships, is essential to understand the entire process in detail, before starting any study for the development of a maintenance performance measurement system in organizations with some complexity, so that this implementation can be done with the least possible difficulty [83]. It is not too much to repeat that the failure rate in the implementation of these systems is very high (70\%) ([15] and [16]), within the few attempts at implementation that are attempted.

The fundamental objective of managers is to maximize the profit of organizations and, to achieve this, the contribution of maintenance is increasingly important. Thus, a different approach is needed to make top management aware of the need to be involved in the maintenance improvement process [6].

A performance management system acts as an early warning system [83] and can promote a management system for maintaining knowledge within the company, which is certainly one of the main concerns of top management.

As subjectivity grows, with the increasing integration of information into higher-level indicators [49], great care must be taken when preparing executive reports. Active support from top management to the maintenance performance measurement system is achieved using useful and accurate information at the right time.

Also, the environmental, safety and health issues, with the enormous legislative burden they have, give maintenance managers a unique responsibility in managing the risk of the installations, since the maintenance actions or omissions contribute to the level of risk to be reached. that the organization, its workers and the surrounding communities are exposed [64], being matters of close monitoring by top management, for their direct consequences.

From the maintenance manager's perspective, resources are costly, finite and usually below the level they should be, which is why they must be applied in fact where they are important. The degree of importance of each machine, operation or process must be clear at all levels: operational, control, and management, and it must derive from the company's strategy. 
Production interruptions, breakdowns, power failures, lack of labour, stock rupture, intervention requests and others, affect production making the maintenance planning process dynamic. The limited existing capacities must be shared by all systems that need them all the time and this competition can result in waiting times for some of those systems. Maintenance must achieve its defined objectives through production objectives and, simultaneously manage operational constraints with production [41] Performance measurement helps to show and decide from existing trade-offs in all aspects of performance, not all performance indicators will be of equal importance for all operations and will have a profit or loss ratio or other [102].

The trend in the use of performance measurement systems in maintenance shows that more complex systems are being abandoned in favour of simpler models, also demonstrates that the use of standard management systems is a way of not implementing these systems, as it is necessary to have a great knowledge of the maintenance process in question as well as its strategic positioning in each organization [49].

For the implementation of a system to be successful it is imperative to obtain support from top management, which will only exist when it is shown the importance of maintenance.

With the selection of performance indicators appropriate to each area, it is possible to detect deviations at initial stages, identifying the origins of these deviations, and thus achieve problem solving and more economical continuous improvements [1]. Below are some examples of indicators that can be used in the maintenance management of some organizations:

- Activity indicators

- Number of interventions by type of maintenance;

- Degree of compliance with preventive maintenance plans;

- Percentage of Preventive versus Corrective Maintenance.

- Indicators of effectiveness

- Reliability (MTBF);

- Maintainability (MTTR);

- Availability.

- Financial indicators

- Damage repair cost;

- Maintenance cost per equipment / bus;

- Cost / Km or Hour of the equipment / bus;

- Cost of subcontracted maintenance.

- Equipment / bus ROI.

[105] critically analyse the standardized indicators, in order to find the essential indicators to guide the maintenance values and to estimate the Net Present
Value (NPV), terminology that contains the performance guidelines and maintenance indicators has few published, and is not described in detail, namely in asset management.

[50] provide an overview of the research and development of the measurement of maintenance performance, they consider the various measurement problems and comment on the lack of structure and references for measuring maintenance performance. The focus is to determine how value can be created for organizations, measuring maintenance performance, examining maintenance strategies, such as condition-based maintenance, reliabilitycentered maintenance, etc. In other words, it aims to find structures or models that can be used to evaluate different maintenance strategies and determine the value of those structures for an organization.

According to [35], increasing availability is a classic objective of maintenance services, which implies an increase in equipment reliability (MTBF) and a reduction in intervention times (MTTR), [36], increasing availability consists of reducing the number of stops due to damage and repair and inspection times: from this it is concluded that it is not enough to have reliable equipment to obtain high rates of availability, but that it is also necessary to guarantee maximum speed in repair, maintenance and inspection operations.

In order to improve the availability and operational safety of the equipment, all malfunctions known as having catastrophic consequences must be eliminated, as well as the life of the components must be increased, because each time a breakdown occurs due to a malfunction or replacement of components, check if an important stoppage of the equipment and or a loss of operational safety. The decisive factors to prevent this from happening are based on a correct design of the equipment and installations, and on an effective and efficient maintenance, after its start-up [37].

The indicators of the quality criteria most valued in terms of importance given by the regular transport customer are the reliability of the equipment and its availability, as their malfunctions lead to increases in waiting times, leading to punctuality failures and non-compliance with timetables, which are decisive factors for the choice of transport to be taken by the end customer.

The service provider must pay attention to the size of its fleet, and the quantity must meet the needs, the larger the size of the fleet, the greater the investments with its acquisition and maintenance. Thus, and in accordance with the principles of rationalization of investments and minimization of costs, the actions taken should be directed towards increasing the availability of buses. 
According to [2], there are some methods for evaluating investments. For example, decision trees can be used to make a probabilistic analysis of the various possible scenarios or use traditional methods, translated into the form of financial indicators. As an example of financial indicators of these methods, we can refer to the Net Present Value (VAL), the payback (which corresponds to the investment recovery period), the Internal Rate of Return (IRR), and the Return on Investment (ROI).

The economic climate is increasingly complex, and organizations have an absolute need to improve their performance, by increasing their ROI ratios [36].

In this context, industrial organizations of all types and sizes, but especially those with capital intensive, must face levels of uncertainty, as to whether or not they are able to achieve their economic and financial objectives, [6], the effect of this uncertainty on the objectives of organizations represents the "risk". In order to ensure that this risk is controlled and that the ROI ratios are ensured in a sustained manner, it is necessary to manage the equipment taking into account its entire life cycle.

In finance, ROI and the Rate of Return (ROR), profit rate or simply return, is the relationship between the amount of money earned (or lost) as a result of an investment and the amount of money invested.

Advance knowledge has an important impact not only within the organization that manages the investment process, but also with potential investors. In addition to the internal and external "sale" of the equipment, it is essential for its monitoring, giving a clear indication of the impact of physical assets on the business in relation to the pre-defined goals.

The innovation that differentiates the approach, which will be presented in this article, lies in the fact that improved econometric models were developed through the introduction of maintenance KPI which allows a better monitoring of the equipment's LCC.

\section{Econometric Models}

This model of analysis allows determining the most rational period for replacing buses and, consequently, the Reserve Fleet, given that the first involves the second. This approach is valid for new and used buses. Obviously, the technological and environmental aspects are left out of this analysis.

To give the final step to implement the integrated model for determining the reserve fleet, we will discuss the influence of MTTR on the Economic Cycle for replacing buses throughout their life cycle. It is also intended to integrate the ROI of a bus with the replacement business cycle. For this, several systems of equations are presented, starting with the Uniform Annual Income Method (RAUn), taking into account the Return on Investment (ROI) as a function of the Mean Time of Repair (MTTR).
The first tool that is necessary to introduce is the exponential smoothing, it's very important for the prediction of the oil degradation. The formula for exponential smoothing is given by:

$$
\begin{aligned}
& S_{t+1}=\alpha \times x_{t}+(1-\alpha) S_{t} \Leftrightarrow S_{t+1}=\alpha \sum_{i=0}^{t}(1-\alpha)^{i} x_{t-i} \\
& 0 \leq \alpha \leq 1 \\
& \text { Where, } \\
& S_{t+1} \quad \text { Is the forecast for the next time; } \\
& x_{t} \quad \text { Is the real value recorded in the present time; } \\
& S_{t} \quad \text { Is the forecasted value for the present time; } \\
& \alpha \quad \text { Is the smoothing parameter. }
\end{aligned}
$$

Based on this tool, and the result of the oil analysis, namely Soot, among others, it is possible to forecast the next maintenance intervention based on the oil condition.

The econometric models to support the evaluation of the bus's replacement time and some additional considerations to aid their analysis, are made next.

There are several reasons to make economic simulations to evaluate the need to replace equipment. Deterioration is one of the main reasons to replace equipment, because the operating, maintenance and functioning costs rise. However, it is important to pick the correct method to determine the right time to replace equipment. To do this, it is necessary to consider the following variables: acquisition cost, value of withdrawal, operating costs, maintenance costs, operating costs, inflation rate, and discount rate.

The most values of the variables can be obtained from historical data, except for the withdrawal value. However, it may be not easy to get the market value for an equipment in particular. One solution is to simulate devaluation using one of the following methods ([32], [33] and [76]):

i) Linear depreciation method - the decline of the value of the equipment is constant along the years;

ii) Method of the sum of the digits - the annual depreciation is not linear, being almost exponential;

iii) The Exponential method - the annual depreciation charge is exponential along the time.

According to [32] equipment can be replaced by various criteria. A common criterion is the economic 
cycle; in this approach, the optimal period to replace is which that minimizes the average total costs of operation, maintenance and capital immobilization.

Another popular method is the lifespan approach; in this approach, the optima time to replace is when the operating costs exceed the costs of maintenance plus the amortization of the capital cost of a new and equivalent piece of equipment.

Two relevant variables above referred that must be considered are:

i) real discount rate, $i$;

ii) inflation rate, $\theta$.

These rates are related as follow:

$i_{A}=i+i+\theta \times \theta$

where $i_{A}$ is the Apparent Rate.

This paper uses the Uniform Method of Annual Income (RAU) to determine the best time to replace a bus in an urban transportation fleet. This method needs the following data:

i) Equipment acquisition cost;

ii) Withdrawal values (calculated according to the above methods);

iii) Maintenance Costs and Exploration over the years;

iv) Apparent Rate.

The Net Present Value in year $n(V P L n)$ is given by:

$V P L_{n}=C A+\sum_{j=0}^{n} \frac{C M_{j}+C O_{j}}{\left(1+i_{A}\right)^{j}}-\frac{V_{n}}{\left(1+i_{A}\right)^{j}}$

Where,

$C A \quad$ Equipment Cost of Acquisition;

$C M_{j} \quad$ Cost of Maintenance in year $j=1,2,3, \ldots n$;

$\mathrm{CO}_{j} \quad$ Cost of Operation in year $j=1,2,3, \ldots n$;

$i_{A} \quad$ Apparent rate;

$V_{n} \quad$ Value of the equipment over a period $n=1,2,3 \ldots n$

The Annual (n) Uniform Annual Rent $\left(\mathrm{RAU}_{\mathrm{n}}\right)$ is given by:

$R A U_{n}=\frac{i_{A}\left(1+i_{A}\right)^{j}}{\left(1+i_{A}\right)^{j}-1} * V P L_{n}$

Where $R A U_{n}$ indicates the period (multi-year) within which the equipment ought to be replaced. This value is equivalent to a minimum rent that the equipment would cost annually.

The $R A U$ indicates the period (in years), when a bus ought to be replaced. This value is equivalent to the minimum annual cost of the bus.

To apply the models, we consider variables related to direct operating and maintenance costs, as well as the relevant economic indicators, such as inflation and interest rates.
Initially, we performed a survey of the operating data for the Life Cycle Cost (LCC) from a bus fleet belonging to a medium-sized public urban transport company.

Another important variable that must be considered in econometric models to replace equipment is the Cost of Maintenance (CM). This variable is very relevant in determining the most adequate time to replace an equipment, in this case an urban passenger bus. One of the advantages of condition monitoring maintenance (with prediction) based on oil analysis is the reduction of maintenance costs, what also influences the replacement time. Monitoring the degradation of oil influences the maintenance KPI's, namely, the Mean Time to Repair (MTTR) and the Mean Time Between Failures (MTBF): lower MTTR and higher MTBF values indicate that maintenance is supporting well the production operations, because the availability increases. The following equations express the Availability (A), the MTTR and the MTBF respectively:

$A=\frac{M T B F}{M T B F+M T T R}$

$M T T R=M T B F \times \frac{(1-A)}{A}$

$M T B F=\frac{M T T R}{\frac{(1-A)}{A}}$

To determine the size of the reserve fleet, the following calculation can be used:

$F R=\frac{m \times M T T R}{k}$

where

FR Reserve Fleet;

$m \quad$ Number of fleet buses;

MTTR Mean Time To Repair;

$k \quad$ Number of days per year.

\section{Predictive Maintenance versus reserve fleet}

The Life Cycle Cost (LCC) of equipment covers their all costs, from project to disposal; it is a very important approach for determining the optimum time for replacement of a bus.

When deciding on equipment management, the maintenance costs, the operating costs, the total cost of ownership, the accrued costs, and the Return on Investment (ROI) are considered.

The previous section describes the models and tools necessary to implement an integrated model for determining the reserve fleet. Based on them, it can be implemented a new integrated management model that can be named by: Integrated Model for Evaluation of the Reserve Fleet (MIAFRA), which is summarized in the following approach: 
- Econometric models for determining the minimum $\mathrm{LCC}$ value

○ Uniform Annual Income considering the following variables:

- Functioning costs

- Maintenance Costs

- Fuel Costs

- Replacement Value

- Inflation Rate

- Capitalisation Rate

- Useful life model considering the following variables:

- Functioning costs

- Maintenance Costs

- Fuel Costs

- Replacement Costs

- Inflation Rate

- Capitalisation Rate

- Conditioning / predictive maintenance models to maximize availability
$\circ$ MTBF
○ MTTR
- Availability

The above approaches constitute a single model of analysis that allows determining the most rational period for replacing buses and, consequently, the Reserve Fleet, given that the first involves the second.

It should be noted that the previous integrated approach is valid for new and used buses, considering the effect of monetary correction. Obviously, the technological and environmental aspects are left out of this analysis.

Next, to give the final step to implement the integrated model for determining the reserve fleet, we will discuss the influence of MTTR on the Economic Cycle for replacing buses throughout their life cycle. It is also intended to integrate the ROI of a bus with the replacement business cycle. For this, several systems of equations are presented, starting with the Uniform Annual Income Method $\left(R A U_{n}\right)$, considering the Return on Investment (ROI) as a function of the Mean Time of Repair (MTTR).

$\left\{\begin{array}{c}R A U_{n}=\frac{i_{A}\left(1+i_{A}\right)^{n}}{\left(1+i_{A}\right)^{n}-1} *\left(C A+\sum_{j=0}^{n} \frac{\left(t * M T T R * \frac{C M_{j}}{d}\right)+C O_{j}}{\left(1+i_{A}\right)^{j}}-\frac{V_{n}}{\left(1+i_{A}\right)^{n}}\right) \\ R O I=\sum_{j=1}^{n} \frac{C F_{j}}{\left(1+i_{A}\right)^{j}}-C A\end{array}\right.$

Being, $\begin{array}{ll}t & \text { Number of periods considered for MTTR } \\ d & \text { Number of days per year }\end{array}$

The Total Average Cost Minimization Method (MCMT) and the ROI as a function of MTTR can be described as follows:

$\left\{\begin{array}{c}C_{n(M C M T)}=\min _{n \in\{1,2, \ldots, N\}} \frac{1}{n}\left(C A-V_{n}+\sum_{j=1}^{n}\left(\left(t * M T T R * \frac{C M_{j}}{d}\right)+C O_{j}\right)\right) \\ R O I=\sum_{j=1}^{n} \frac{C F_{j}}{\left(1+i_{A}\right)^{j}}-C A\end{array}\right.$

MCMT with Reduction to Present Value (MCMTRVP) and the ROI as a function of MTTR can be written as follows:

$\left\{\begin{array}{c}C_{n(M C M T-R V P)}=\min _{n \in\{1,2, \ldots, N\}} \frac{1}{n}\left(C A-\frac{V_{n}}{\left(1+i_{A}\right)^{n}}+\sum_{j=1}^{n}\left(\frac{\left(t * M T T R * \frac{C M_{j}}{d}\right)+C O_{j}}{\left(1+i_{A}\right)^{j}}\right)\right) \\ R O I=\sum_{j=1}^{n} \frac{C F_{j}}{\left(1+i_{A}\right)^{j}}-C A\end{array}\right.$

Throughout the paper, the importance of monitoring the condition, its relationship with the MTTR and the importance of this KPI for the temporary replacement of a bus was highlighted. To show this relevance, an example of the influence of this reason is given, using the Uniform Annual Income Method. Table 1 and Figure 1 demonstrates the influence of MTTR on the bus replacement time. To simulate this influence, values of $5,10,20,25,30$ and 35 days were used for MTTR.

Table 2 and Figure 2 shows the influence of MTTR on econometric models. An increase or decrease in MTTR over time varies the point of withdrawal from the equipment. The replacement point can vary by more than nine years. That is, the replacement time is five years, but if there is a decrease in MTTR, the replacement time increases to 14 years.

Additionally, it is relevant to analyse the influence of economic indicators for the evaluation of investments, such as ROI. To emphasize its importance, the influence of MTTR versus ROI on econometric models can be verified. 
Table 1 - Influence of MTTR on RAU

\begin{tabular}{|c|c|c|c|c|c|c|c|c|c|c|c|c|c|c|c|c|c|}
\hline \multicolumn{12}{|c|}{ Vehicles } & \multicolumn{6}{|c|}{ RAU[€ Year n] } \\
\hline Year $\mathrm{j}$ & $\mathrm{CA}[€]$ & $\phi[\%]$ & i [\%] & $\mathbf{i}_{\mathrm{A}}$ & $\mathrm{i}_{\mathrm{A}}[\%]$ & MTTR $_{1}$ & MTTR $_{2}$ & MTTR $_{3}$ & MTTR $_{4}$ & MTTR $_{5}$ & MTTR $_{6}$ & RAU \& MTTR & RAU \& MTTR $_{2}$ & ${ }_{2}$ RAU \& $\mathrm{MTTR}_{3}$ & ${ }_{3}$ RAU \& MTTR & RAU \& MTTR & RAU \& MTTR 6 \\
\hline 0 & $110,66 \mathrm{~K}$ & $4 \%$ & $4 \%$ & 0,08 & $8 \%$ & & & & & & & & & & & & \\
\hline 1 & & $4 \%$ & $4 \%$ & 0,08 & $8 \%$ & 5 & 10 & 20 & 25 & 30 & 35 & $25,99 \mathrm{~K}$ & $26,20 \mathrm{~K}$ & $26,61 \mathrm{~K}$ & $26,81 \mathrm{~K}$ & $27,02 \mathrm{~K}$ & $27,22 \mathrm{~K}$ \\
\hline 2 & & $4 \%$ & $4 \%$ & 0,08 & $8 \%$ & 5 & 10 & 20 & 25 & 30 & 35 & $24,88 \mathrm{~K}$ & $25,18 \mathrm{~K}$ & $25,79 \mathrm{~K}$ & $26,09 \mathrm{~K}$ & $26,40 \mathrm{~K}$ & $26,70 \mathrm{~K}$ \\
\hline 3 & & $4 \%$ & $4 \%$ & 0,08 & $8 \%$ & 5 & 10 & 20 & 25 & 30 & 35 & $23,94 \mathrm{~K}$ & $24,34 \mathrm{~K}$ & $25,14 \mathrm{~K}$ & $25,54 \mathrm{~K}$ & $25,95 \mathrm{~K}$ & $26,35 \mathrm{~K}$ \\
\hline 4 & & $4 \%$ & $4 \%$ & 0,08 & $8 \%$ & 5 & 10 & 20 & 25 & 30 & 35 & $23,17 \mathrm{~K}$ & $23,67 \mathrm{~K}$ & $24,65 \mathrm{~K}$ & $25,15 \mathrm{~K}$ & $25,64 \mathrm{~K}$ & $26,13 \mathrm{~K}$ \\
\hline 5 & & $4 \%$ & $4 \%$ & 0,08 & $8 \%$ & 5 & 10 & 20 & 25 & 30 & 35 & $22,54 \mathrm{~K}$ & $23,12 \mathrm{~K}$ & $24,29 \mathrm{~K}$ & $24,87 \mathrm{~K}$ & $25,46 \mathrm{~K}$ & $26,04 \mathrm{~K}$ \\
\hline 6 & & $4 \%$ & $4 \%$ & 0,08 & $8 \%$ & 5 & 10 & 20 & 25 & 30 & 35 & $22,02 \mathrm{~K}$ & $22,69 \mathrm{~K}$ & $24,04 \mathrm{~K}$ & $24,71 \mathrm{~K}$ & $25,38 \mathrm{~K}$ & $26,05 \mathrm{~K}$ \\
\hline 7 & & $4 \%$ & $4 \%$ & 0,08 & $8 \%$ & 5 & 10 & 20 & 25 & 30 & 35 & $21,61 \mathrm{~K}$ & $22,36 \mathrm{~K}$ & $23,88 \mathrm{~K}$ & $24,64 \mathrm{~K}$ & $25,39 \mathrm{~K}$ & $26,15 \mathrm{~K}$ \\
\hline 8 & & $4 \%$ & $4 \%$ & 0,08 & $8 \%$ & 5 & 10 & 20 & 25 & 30 & 35 & $21,28 \mathrm{~K}$ & $22,12 \mathrm{~K}$ & $23,80 \mathrm{~K}$ & $24,64 \mathrm{~K}$ & $25,48 \mathrm{~K}$ & $26,32 \mathrm{~K}$ \\
\hline 9 & & $4 \%$ & $4 \%$ & 0,08 & $8 \%$ & 5 & 10 & 20 & 25 & 30 & 35 & $21,03 \mathrm{~K}$ & $21,95 \mathrm{~K}$ & $23,79 \mathrm{~K}$ & $24,71 \mathrm{~K}$ & $25,63 \mathrm{~K}$ & $26,55 \mathrm{~K}$ \\
\hline 10 & & $4 \%$ & $4 \%$ & 0,08 & $8 \%$ & 5 & 10 & 20 & 25 & 30 & 35 & $20,84 \mathrm{~K}$ & $21,84 \mathrm{~K}$ & $23,83 \mathrm{~K}$ & $24,83 \mathrm{~K}$ & $25,83 \mathrm{~K}$ & $26,83 \mathrm{~K}$ \\
\hline 11 & & $4 \%$ & $4 \%$ & 0,08 & $8 \%$ & 5 & 10 & 20 & 25 & 30 & 35 & $20,70 \mathrm{~K}$ & $21,78 \mathrm{~K}$ & $23,92 \mathrm{~K}$ & $25,00 \mathrm{~K}$ & $26,07 \mathrm{~K}$ & $27,15 \mathrm{~K}$ \\
\hline 12 & & $4 \%$ & $4 \%$ & 0,08 & $8 \%$ & 5 & 10 & 20 & 25 & 30 & 35 & $20,62 \mathrm{~K}$ & $21,76 \mathrm{~K}$ & $24,06 \mathrm{~K}$ & $25,20 \mathrm{~K}$ & $26,35 \mathrm{~K}$ & $27,49 \mathrm{~K}$ \\
\hline 13 & & $4 \%$ & $4 \%$ & 0,08 & $8 \%$ & 5 & 10 & 20 & 25 & 30 & 35 & $20,57 \mathrm{~K}$ & $21,79 \mathrm{~K}$ & $24,22 \mathrm{~K}$ & $25,44 \mathrm{~K}$ & $26,65 \mathrm{~K}$ & $27,87 \mathrm{~K}$ \\
\hline 14 & & $4 \%$ & $4 \%$ & 0,08 & $8 \%$ & 5 & 10 & 20 & 25 & 30 & 35 & $20,56 \mathrm{~K}$ & $21,84 \mathrm{~K}$ & $24,41 \mathrm{~K}$ & $25,69 \mathrm{~K}$ & $26,98 \mathrm{~K}$ & $28,26 \mathrm{~K}$ \\
\hline 15 & & $4 \%$ & $4 \%$ & 0,08 & $8 \%$ & 5 & 10 & 20 & 25 & 30 & 35 & $20,57 \mathrm{~K}$ & $21,92 \mathrm{~K}$ & $24,62 \mathrm{~K}$ & $25,97 \mathrm{~K}$ & $27,32 \mathrm{~K}$ & $28,67 \mathrm{~K}$ \\
\hline 16 & & $4 \%$ & $4 \%$ & 0,08 & $8 \%$ & 5 & 10 & 20 & 25 & 30 & 35 & $20,61 \mathrm{~K}$ & $22,02 \mathrm{~K}$ & $24,85 \mathrm{~K}$ & $26,26 \mathrm{~K}$ & $27,67 \mathrm{~K}$ & $29,09 \mathrm{~K}$ \\
\hline 17 & & $4 \%$ & $4 \%$ & 0,08 & $8 \%$ & 5 & 10 & 20 & 25 & 30 & 35 & $20,67 \mathrm{~K}$ & $22,14 \mathrm{~K}$ & $25,09 \mathrm{~K}$ & $26,56 \mathrm{~K}$ & $28,04 \mathrm{~K}$ & $29,51 \mathrm{~K}$ \\
\hline 18 & & $4 \%$ & $4 \%$ & 0,08 & $8 \%$ & 5 & 10 & 20 & 25 & 30 & 35 & $20,74 \mathrm{~K}$ & $22,28 \mathrm{~K}$ & $25,34 \mathrm{~K}$ & $26,87 \mathrm{~K}$ & $28,40 \mathrm{~K}$ & $29,94 \mathrm{~K}$ \\
\hline 19 & & $4 \%$ & $4 \%$ & 0,08 & $8 \%$ & 5 & 10 & 20 & 25 & 30 & 35 & $20,83 \mathrm{~K}$ & $22,42 \mathrm{~K}$ & $25,60 \mathrm{~K}$ & $27,18 \mathrm{~K}$ & $28,77 \mathrm{~K}$ & $30,36 \mathrm{~K}$ \\
\hline 20 & & $4 \%$ & $4 \%$ & 0,08 & $8 \%$ & 5 & 10 & 20 & 25 & 30 & 35 & $20,93 \mathrm{~K}$ & $22,57 \mathrm{~K}$ & $25,86 \mathrm{~K}$ & $27,50 \mathrm{~K}$ & $29,14 \mathrm{~K}$ & $30,79 \mathrm{~K}$ \\
\hline 21 & & $4 \%$ & $4 \%$ & 0,08 & $8 \%$ & 5 & 10 & 20 & 25 & 30 & 35 & $21,04 \mathrm{~K}$ & $22,73 \mathrm{~K}$ & $26,12 \mathrm{~K}$ & $27,82 \mathrm{~K}$ & $29,51 \mathrm{~K}$ & $31,21 \mathrm{~K}$ \\
\hline
\end{tabular}

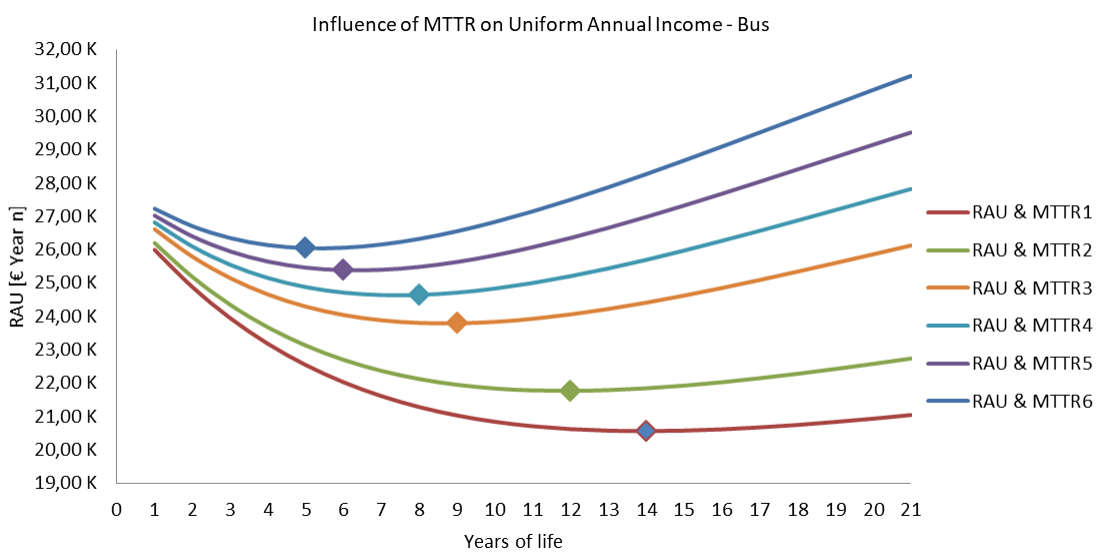

Fig. 1 - Influence of MTTR on RAU

Table 2 - Influence of MTTR on RAU+ROI

\begin{tabular}{|c|c|c|c|c|c|c|c|c|c|c|c|c|c|c|c|}
\hline \multicolumn{9}{|c|}{ Vehicles } & \multicolumn{7}{|c|}{$\operatorname{RAU}[€$ Year $\mathrm{n}]$} \\
\hline Year $\mathrm{j}$ & $\mathrm{CA}[€]$ & $\mathrm{i}_{\mathrm{A}}[\%]$ & MTTR $_{1}$ & MTTR $_{2}$ & $\mathrm{MTTR}_{3}$ & $\mathrm{MTTR}_{4}$ & MTTR $_{5}$ & MTTR $_{6}$ & RAU \& MTTR & RAU \& MTTR $_{2}$ & RAU \& $\mathrm{MTTR}_{3}$ & $\mathrm{RAU} \& \mathrm{MTTR}_{4}$ & RAU \& MTTR $_{5}$ & RAU \& MTTR $_{6}$ & ROI \\
\hline 0 & $110,66 \mathrm{~K}$ & $8 \%$ & & & & & & & & & & & & & \\
\hline 1 & & $8 \%$ & 5 & 10 & 20 & 25 & 30 & 35 & $25,99 \mathrm{~K}$ & $26,20 \mathrm{~K}$ & $26,61 \mathrm{~K}$ & $26,81 \mathrm{~K}$ & $27,02 \mathrm{~K}$ & $27,22 \mathrm{~K}$ & $-87,51 \mathrm{~K}$ \\
\hline 2 & & $8 \%$ & 5 & 10 & 20 & 25 & 30 & 35 & $24,88 \mathrm{~K}$ & $25,18 \mathrm{~K}$ & $25,79 \mathrm{~K}$ & $26,09 \mathrm{~K}$ & $26,40 \mathrm{~K}$ & $26,70 \mathrm{~K}$ & $-70,36 \mathrm{~K}$ \\
\hline 3 & & $8 \%$ & 5 & 10 & 20 & 25 & 30 & 35 & $23,94 \mathrm{~K}$ & $24,34 \mathrm{~K}$ & $25,14 \mathrm{~K}$ & $25,54 \mathrm{~K}$ & $25,95 \mathrm{~K}$ & $26,35 \mathrm{~K}$ & $-54,57 \mathrm{~K}$ \\
\hline 4 & & $8 \%$ & 5 & 10 & 20 & 25 & 30 & 35 & $23,17 \mathrm{~K}$ & $23,67 \mathrm{~K}$ & $24,65 \mathrm{~K}$ & $25,15 \mathrm{~K}$ & $25,64 \mathrm{~K}$ & $26,13 \mathrm{~K}$ & $-40,01 K$ \\
\hline 5 & & $8 \%$ & 5 & 10 & 20 & 25 & 30 & 35 & $22,54 \mathrm{~K}$ & $23,12 \mathrm{~K}$ & $24,29 K$ & $24,87 \mathrm{~K}$ & $25,46 \mathrm{~K}$ & $26,04 \mathrm{~K}$ & $-26,61 K$ \\
\hline 6 & & $8 \%$ & 5 & 10 & 20 & 25 & 30 & 35 & $22,02 \mathrm{~K}$ & $22,69 \mathrm{~K}$ & $24,04 \mathrm{~K}$ & $24,71 \mathrm{~K}$ & $25,38 \mathrm{~K}$ & $26,05 \mathrm{~K}$ & $-14,25 K$ \\
\hline 7 & & $8 \%$ & 5 & 10 & 20 & 25 & 30 & 35 & $21,61 \mathrm{~K}$ & $22,36 \mathrm{~K}$ & $23,88 \mathrm{~K}$ & $24,64 \mathrm{~K}$ & $25,39 \mathrm{~K}$ & $26,15 \mathrm{~K}$ & $-2,88 \mathrm{~K}$ \\
\hline 8 & & $8 \%$ & 5 & 10 & 20 & 25 & 30 & 35 & $21,28 \mathrm{~K}$ & $22,12 \mathrm{~K}$ & $23,80 \mathrm{~K}$ & $24,64 \mathrm{~K}$ & $25,48 \mathrm{~K}$ & $26,32 \mathrm{~K}$ & $7,61 \mathrm{~K}$ \\
\hline 9 & & $8 \%$ & 5 & 10 & 20 & 25 & 30 & 35 & $21,03 \mathrm{~K}$ & $21,95 \mathrm{~K}$ & $23,79 \mathrm{~K}$ & $24,71 \mathrm{~K}$ & $25,63 \mathrm{~K}$ & $26,55 \mathrm{~K}$ & $17,26 \mathrm{~K}$ \\
\hline 10 & & $8 \%$ & 5 & 10 & 20 & 25 & 30 & 35 & $20,84 \mathrm{~K}$ & $21,84 \mathrm{~K}$ & $23,83 \mathrm{~K}$ & $24,83 \mathrm{~K}$ & $25,83 \mathrm{~K}$ & $26,83 \mathrm{~K}$ & $26,15 \mathrm{~K}$ \\
\hline 11 & & $8 \%$ & 5 & 10 & 20 & 25 & 30 & 35 & $20,70 \mathrm{~K}$ & $21,78 \mathrm{~K}$ & $23,92 \mathrm{~K}$ & $25,00 \mathrm{~K}$ & $26,07 \mathrm{~K}$ & $27,15 \mathrm{~K}$ & $34,35 \mathrm{~K}$ \\
\hline 12 & & $8 \%$ & 5 & 10 & 20 & 25 & 30 & 35 & $20,62 \mathrm{~K}$ & $21,76 \mathrm{~K}$ & $24,06 \mathrm{~K}$ & $25,20 \mathrm{~K}$ & $26,35 \mathrm{~K}$ & $27,49 \mathrm{~K}$ & $41,89 \mathrm{~K}$ \\
\hline 13 & & $8 \%$ & 5 & 10 & 20 & 25 & 30 & 35 & $20,57 \mathrm{~K}$ & $21,79 \mathrm{~K}$ & $24,22 \mathrm{~K}$ & $25,44 \mathrm{~K}$ & $26,65 \mathrm{~K}$ & $27,87 \mathrm{~K}$ & $48,84 \mathrm{~K}$ \\
\hline 14 & & $8 \%$ & 5 & 10 & 20 & 25 & 30 & 35 & $20,56 \mathrm{~K}$ & $21,84 \mathrm{~K}$ & $24,41 \mathrm{~K}$ & $25,69 \mathrm{~K}$ & $26,98 \mathrm{~K}$ & $28,26 \mathrm{~K}$ & $55,24 \mathrm{~K}$ \\
\hline 15 & & $8 \%$ & 5 & 10 & 20 & 25 & 30 & 35 & $20,57 \mathrm{~K}$ & $21,92 \mathrm{~K}$ & $24,62 \mathrm{~K}$ & $25,97 \mathrm{~K}$ & $27,32 \mathrm{~K}$ & $28,67 \mathrm{~K}$ & $61,14 \mathrm{~K}$ \\
\hline 16 & & $8 \%$ & 5 & 10 & 20 & 25 & 30 & 35 & $20,61 \mathrm{~K}$ & $22,02 \mathrm{~K}$ & $24,85 \mathrm{~K}$ & $26,26 \mathrm{~K}$ & $27,67 \mathrm{~K}$ & $29,09 \mathrm{~K}$ & $66,56 \mathrm{~K}$ \\
\hline 17 & & $8 \%$ & 5 & 10 & 20 & 25 & 30 & 35 & $20,67 \mathrm{~K}$ & $22,14 \mathrm{~K}$ & $25,09 \mathrm{~K}$ & $26,56 \mathrm{~K}$ & $28,04 \mathrm{~K}$ & $29,51 \mathrm{~K}$ & $71,56 \mathrm{~K}$ \\
\hline 18 & & $8 \%$ & 5 & 10 & 20 & 25 & 30 & 35 & $20,74 \mathrm{~K}$ & $22,28 \mathrm{~K}$ & $25,34 \mathrm{~K}$ & $26,87 \mathrm{~K}$ & $28,40 \mathrm{~K}$ & $29,94 \mathrm{~K}$ & $76,17 \mathrm{~K}$ \\
\hline 19 & & $8 \%$ & 5 & 10 & 20 & 25 & 30 & 35 & $20,83 \mathrm{~K}$ & $22,42 \mathrm{~K}$ & $25,60 \mathrm{~K}$ & $27,18 \mathrm{~K}$ & $28,77 \mathrm{~K}$ & $30,36 \mathrm{~K}$ & $80,41 \mathrm{~K}$ \\
\hline 20 & & $8 \%$ & 5 & 10 & 20 & 25 & 30 & 35 & $20,93 \mathrm{~K}$ & $22,57 \mathrm{~K}$ & $25,86 \mathrm{~K}$ & $27,50 \mathrm{~K}$ & $29,14 \mathrm{~K}$ & $30,79 \mathrm{~K}$ & $84,31 \mathrm{~K}$ \\
\hline 21 & & $8 \%$ & 5 & 10 & 20 & 25 & 30 & 35 & $21,04 \mathrm{~K}$ & $22,73 \mathrm{~K}$ & $26,12 \mathrm{~K}$ & $27,82 \mathrm{~K}$ & $29,51 \mathrm{~K}$ & $31,21 \mathrm{~K}$ & $87,91 \mathrm{~K}$ \\
\hline
\end{tabular}




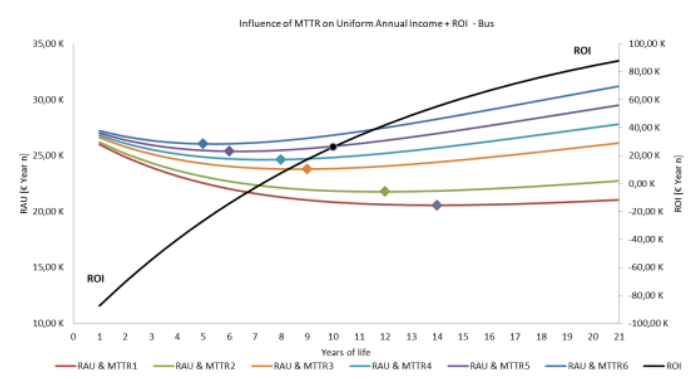

Fig. 2 - Influence of MTTR on RAU+ROI

If the uniform annual income curves are compared with the ROI, it appears that the lower the $R A U_{n}$, the greater the company's profit. Figure 3 focus on a five-day MTTR.

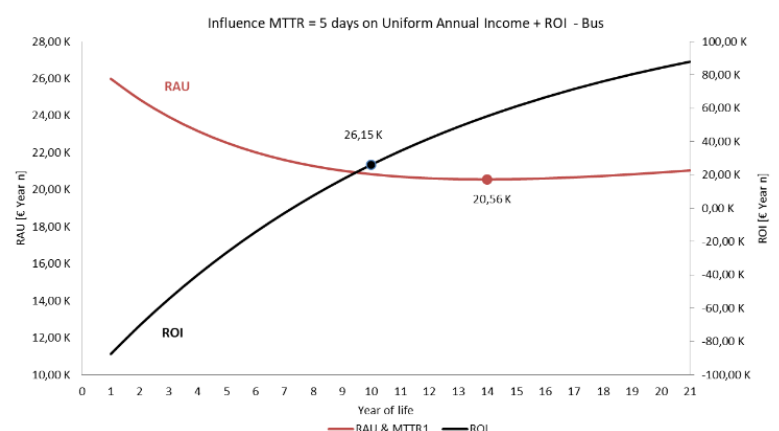

Fig. $3-$ MTTR influence $=5$ days in $R A U+R O I$

It can be noted that for an MTTR $=5$ days, the replacement time is 14 years and the value of the Uniform Annual Income is $€ 20.56 \mathrm{~K}$. It can also be seen that in the 10 th year the ROI value is $€ 26.15 \mathrm{~K}$. Therefore, the ROI is greater than the value of $\mathrm{RAU}_{\mathrm{n}}$, when the equipment starts to make a profit for the company. The period between the year in which the equipment starts to make a profit (year $=10$ ) until the year in which the equipment is replaced corresponds to the year in which the RAU is minimal (year =14), with a profit value of $103,19 \mathrm{~K} €$. The following example (Figure 4) uses data from the previous example, with the MTTR and $\mathrm{RAU}_{\mathrm{n}}$ value, with the highest ROI value per year.

As the value of the ROI is higher each year, the bus starts to make a profit in four years with an ROI of $€$ $55.41 \mathrm{~K}$. Then, from the period when the equipment starts to profit $($ year $=4$ ) until the year when the equipment is replaced, when the Uniform Annual Income is minimal (= 14 years), the profit of the bus is $1905.76 \mathrm{~K} €$.

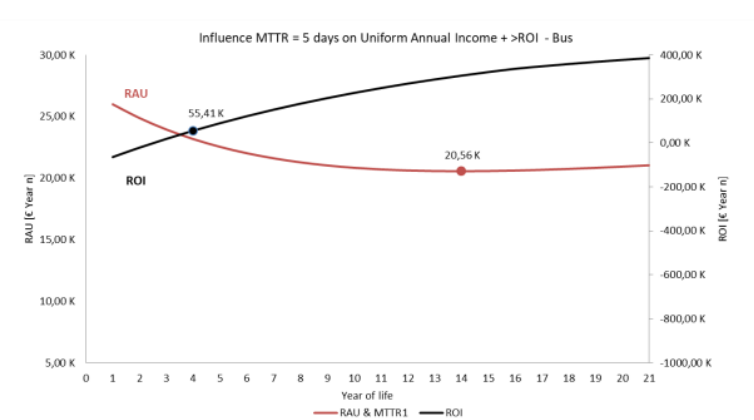

Fig. $4-$ MTTR influence $=5$ days in $R A U+>$ ROI

Figure 5 presents the Model Integrated Reserve Fleet Assessment (MIRFA), which summarizes the global approach referred.

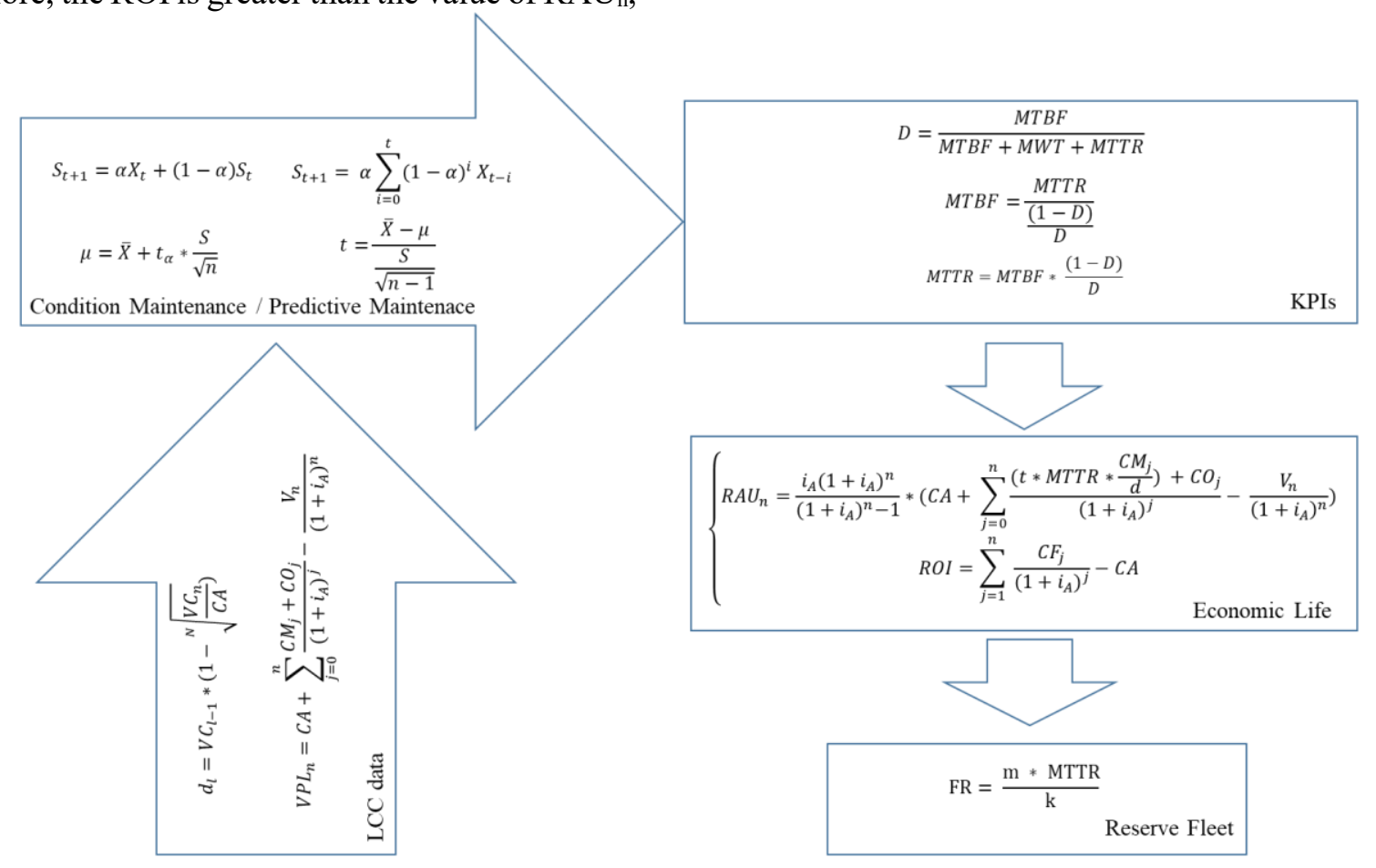

Fig. 5 - Model Integrated Reserve Fleet Assessment (MIRFA) 


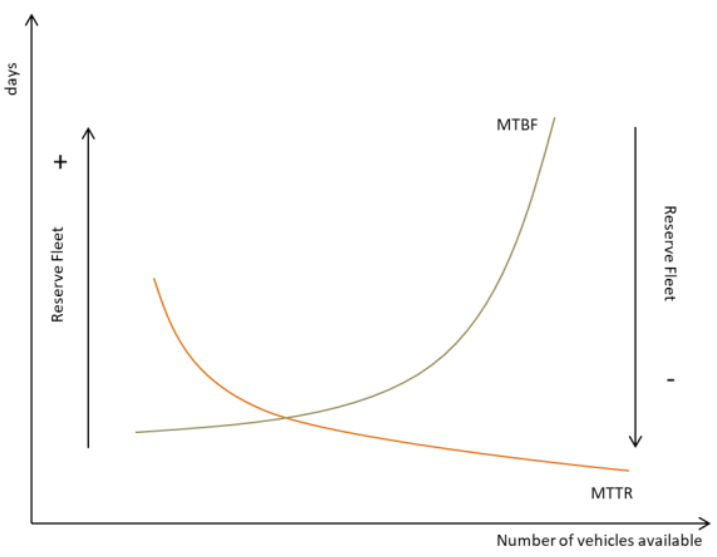

Fig. 6-MTTR and MTBF versus Reserve Fleet

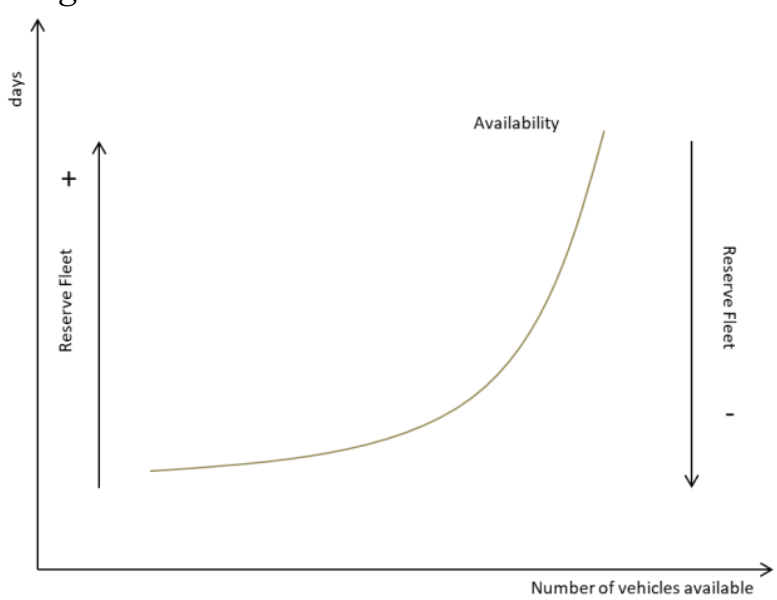

Fig. 7 - Availability versus Reserve Fleet

Figures 6-8 show that, when the MTTR decreases, the availability of the equipment increases.

Although this conclusion seems obvious, these Key Performance Indicators (KPI) are strategic. Thus, the decision maker can decide on the maintenance policy, namely the Condition Monitoring, including the analysis of oils.

Figure 8 illustrates how an increase of the MTBF and a decrease of the MTTR increases the availability of the bus, namely through a predictive maintenance policy. Table 1 and Figures 9 and 10 quantitatively illustrate this relationship. It is obviously important to demonstrate the effect of the interrelation of these indicators in the size of the reserve fleet. We emphasize that reliability's KPI is interlinked with the various indicators presented in the several calculation formulas and it plays a huge impact on the maintenance costs and the size of the reserve fleet.

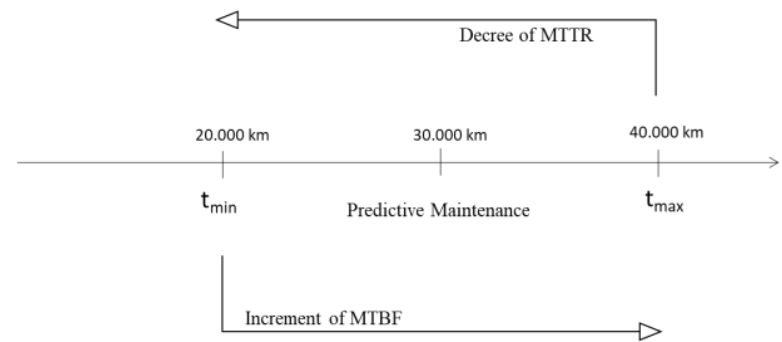

Fig. 8 - Predictive Maintenance versus MTTR/MTBF

Table 3 shows the Availability versus MTTR for a given MTBF, where the availability assumes the following values: $80 \%, 85 \%, 90 \%, 95 \%, 96 \%, 97 \%$, $98 \%$, and $99 \%$.

Table 3 - Availability versus MTTR

\begin{tabular}{c|r|r|r|r|r|r|r|r|r|r}
\hline Availability (\%) & MTBF_1 & MTTR_1 & MTBF_2 & MTTR_2 & MTBF_3 & MTTR_3 & MTBF_4 & MTTR_4 & MTBF_5 & MTTR_5 \\
\hline \hline $80,0 \%$ & 365 & 91 & 360 & 90 & 340 & 85 & 320 & 80 & 300 & 75 \\
$85,0 \%$ & 365 & 64 & 360 & 64 & 340 & 60 & 320 & 56 & 300 & 53 \\
$90,0 \%$ & 365 & 41 & 360 & 40 & 340 & 38 & 320 & 36 & 300 & 33 \\
$95,0 \%$ & 365 & 19 & 360 & 19 & 340 & 18 & 320 & 17 & 300 & 16 \\
$96,0 \%$ & 365 & 15 & 360 & 15 & 340 & 14 & 320 & 13 & 300 & 13 \\
$97,0 \%$ & 365 & 11 & 360 & 11 & 340 & 11 & 320 & 10 & 300 & 9 \\
$98,0 \%$ & 365 & 7 & 360 & 7 & 340 & 7 & 320 & 7 & 300 & 6 \\
$99,0 \%$ & 365 & 4 & 360 & 4 & 340 & 3 & 320 & 3 & 300 & 3 \\
\hline
\end{tabular}

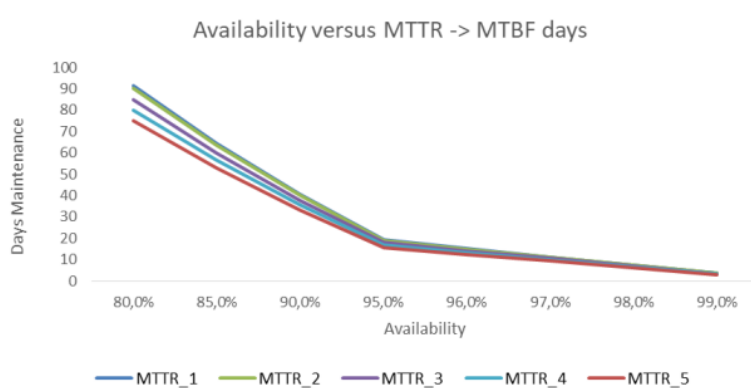

Fig. 9 - Availability graph versus MTTR -> MTBF

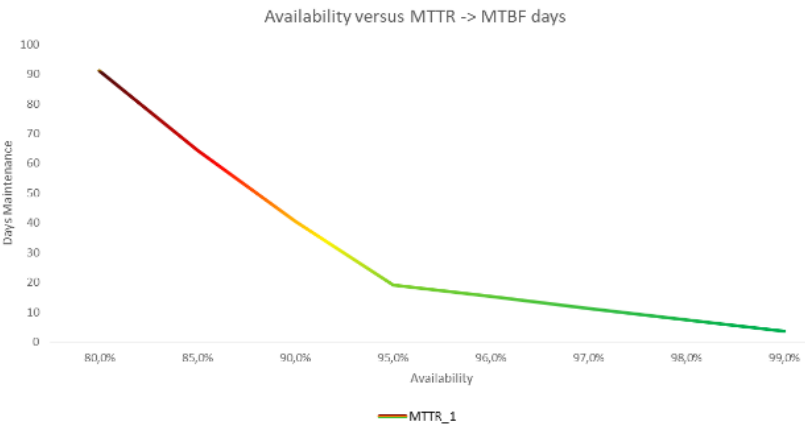

Fig. 10 - Availability graph versus MTTR -> $M T B F$ 
In general, it can be considered that, the more effective the maintenance function in an organization, the lower the equipment failure rate and the less time it takes to solve it. Thus, lower MTTR and higher MTBF values indicate that maintenance is performing well in support of productive operations. It can be seen from Figures 9 and 10 that, when the MTTR decreases, the bus's availability increases. In this sense, it is important to demonstrate the alignment of these indicators with the size of the reserve fleet in transport companies. Considering a real average of the MTTR of a transport company, the following data can be seen in Table 4:

- Availability

$(\%) \quad-\quad$ Availability in percentage;

- Mean MTTR equal to 20 days for unplanned maintenance;

- Current Availability ( $D_{\text {actual }}$ - Availability resulting from the reality of a public transport company, with real MTTR and MTBF values;

- Recommended availability $\left(D_{\text {rec }}\right)$ Availability recommended by the bus brands and oil suppliers to calculate the MTBF and MTTR values;

- Availability inherent to a Condition Maintenance policy - $\left(D_{c b m}\right)$ - Availability based on a conditioning maintenance policy and the MTBF and MTTR values.

Table 4-Availability versus Type of Maintenance/KPI

\begin{tabular}{|c|c|c|c|c|c|c|c|}
\hline \multirow[b]{3}{*}{ Availability (\%) } & \multirow{3}{*}{$\begin{array}{c}\text { Unplanned Maintenance } \\
\text { Medium } \\
\text { MTTR } \\
\end{array}$} & \multicolumn{6}{|c|}{ Unplanned Maintenance + Planned Maintenance } \\
\hline & & \multicolumn{2}{|c|}{$D_{\text {actual }}$} & \multicolumn{2}{|c|}{$D_{\text {rec }}$} & \multicolumn{2}{|c|}{$\mathrm{D}_{\mathrm{cbm}}$} \\
\hline & & MTTR & MTBF & MTRR & MTBF & MTTR & MTBF \\
\hline $80,0 \%$ & 20 & 25 & 100 & 23 & 92 & 21,5 & 86 \\
\hline $85,0 \%$ & 20 & 25 & 142 & 23 & 130 & 21,5 & 122 \\
\hline $90,0 \%$ & 20 & 25 & 225 & 23 & 207 & 21,5 & 194 \\
\hline $91,0 \%$ & 20 & 25 & 253 & 23 & 233 & 21,5 & 217 \\
\hline $92,0 \%$ & 20 & 25 & 288 & 23 & 265 & 21,5 & 247 \\
\hline $93,0 \%$ & 20 & 25 & 332 & 23 & 306 & 21,5 & 286 \\
\hline $94,0 \%$ & 20 & 25 & 392 & 23 & 360 & 21,5 & 337 \\
\hline $95,0 \%$ & 20 & 25 & 475 & 23 & 437 & 21,5 & 409 \\
\hline $96,0 \%$ & 20 & 25 & 600 & 23 & 552 & 21,5 & 516 \\
\hline $97,0 \%$ & 20 & 25 & 808 & 23 & 744 & 21,5 & 695 \\
\hline $98,0 \%$ & 20 & 25 & 1225 & 23 & 1127 & 21,5 & 1054 \\
\hline $99,0 \%$ & 20 & 25 & 2475 & 23 & 2277 & 21,5 & 2129 \\
\hline
\end{tabular}

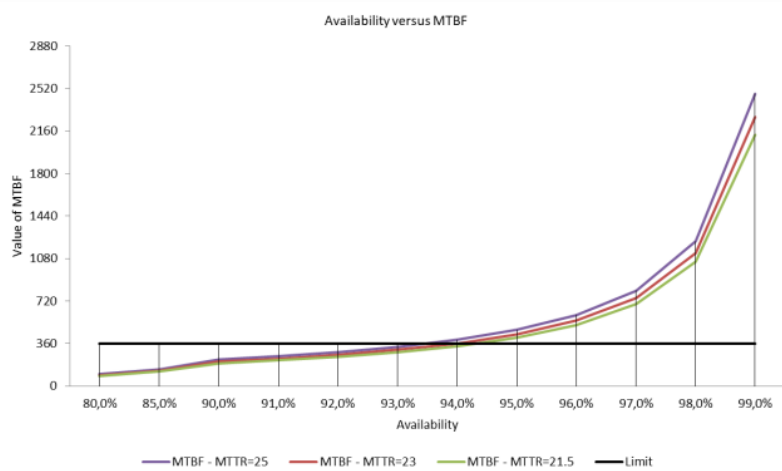

Fig. 11 - Graph of Availability versus MTBF -> MTTR
It can be seen from Table 4 and Figure 11 that Availability may vary by $1 \%$, considering the reduction or increase of oil change intervals. When oil change intervals are reduced, there is a decrease of $1 \%$ in fleet availability, from $94 \%$ to $93 \%$, with a limit of 365 days / year.

In this sequence, the Availability versus Production Requirement (buses necessary to carry out the careers) of the company under study is presented in Table 5 and in the radar map (Figure 12) throughout the year.

Table 5-Availability versus reserve fleet buses

\begin{tabular}{l|c|c|c|c|c}
\multicolumn{1}{c}{ Months } & Bus Fleet & Availability & Need & Maintenance & Reserve Fleet \\
\hline \hline January & 115 & 97 & 90 & 18 & 7 \\
February & 115 & 94 & 90 & 21 & 4 \\
March & 115 & 96 & 90 & 19 & 6 \\
April & 115 & 97 & 90 & 18 & 7 \\
May & 115 & 97 & 90 & 18 & 7 \\
June & 115 & 96 & 90 & 19 & 6 \\
July & 115 & 93 & 90 & 22 & 3 \\
August & 115 & 93 & 90 & 22 & 3 \\
September & 115 & 96 & 90 & 19 & 6 \\
October & 115 & 97 & 90 & 18 & 7 \\
November & 115 & 99 & 90 & 16 & 9 \\
December & 115 & 97 & 90 & 18 & 7
\end{tabular}

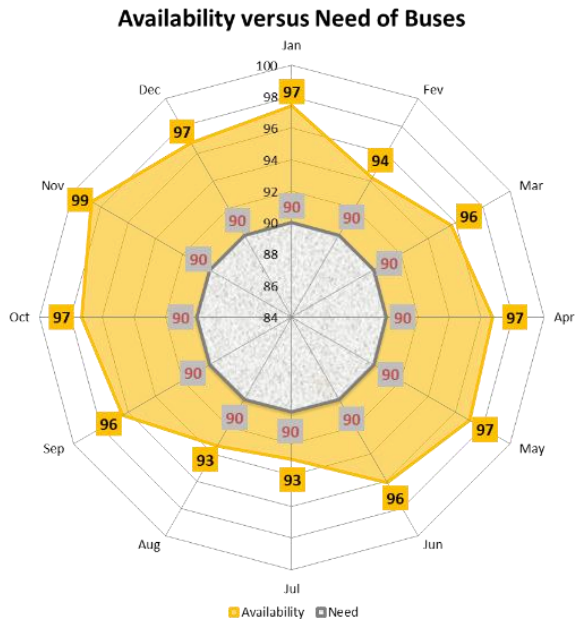

Fig. 12 - Availability Radar Map versus Bus need

In this sequence, the reserve fleet indexed to the MTTR values can now be calculated. Table 6 and Figure 13 show the variation of the size of the reserve fleet according to this indicator.

Table 6-MTTR versus Reserve Fleet

\begin{tabular}{c|c|c|c} 
MTTR & Bus Fleet [k] & Reserve Fleet [FR] & Interval [FR] \\
\hline \hline 5 & 100 & 1,4 & {$[1,2]$} \\
10 & 100 & 2,7 & {$[2,3]$} \\
15 & 100 & 4,1 & {$[4,5]$} \\
20 & 100 & 5,5 & {$[5,6]$} \\
25 & 100 & 6,8 & {$[6,7]$} \\
30 & 100 & 8,2 & {$[8,9]$} \\
\hline
\end{tabular}

From Table 6, the formula (8) can be elaborated to determine the size of the Reserve Fleet:

$F R=\frac{m * M T T R}{k}$ 
Being,

$\begin{array}{ll}F R & \text { Reserve Fleet } \\ m & \text { Number of bus that constitute the } \\ \text { fleet } & \\ \text { MTTR } & \text { Mean Time To Repair } \\ k & \text { Number of days by year (365 days) }\end{array}$

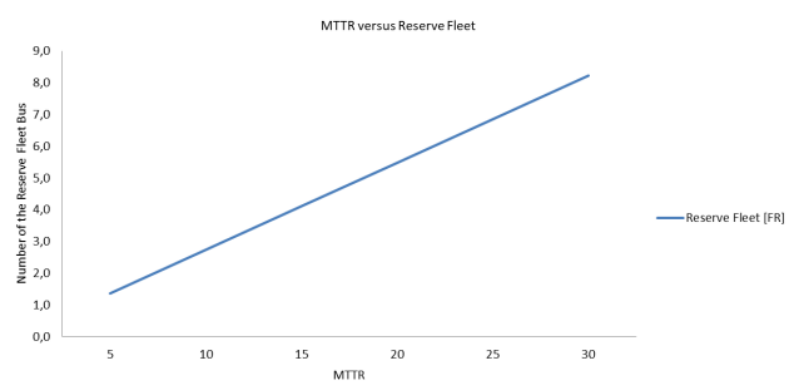

Fig. 13 - Graph of MTTR versus Reserve Fleet

According to Table 6 and Figure 13, the reserve fleet size increases with the MTTR increase. The lower this indicator, the lower the company's investment in a reserve fleet. The emphasis is placed on MTTR because of its high impact on management costs, especially indirect costs. Even a small increase in the value of the MTTR corresponds to an increase in the cost of the Reserve Fleet, due to the high cost of each bus, as mentioned previously.

Thus, it can be concluded that the reliability KPI's under discussion and the maintenance policies practiced by the passenger transport companies have a huge impact on the maintenance costs and the size of the Reserve Fleet.

Next, the calculation of the size of the Reserve Fleet for the company that served as support for this investigation is presented. Table 7 and Figure 14 show the results obtained in the present study.

\section{Table 7 - MTTR versus Reserve Fleet - Company}

\begin{tabular}{c|c|c|c}
\multicolumn{5}{|c}{ under study } \\
MTR [days] & Bus Fleet [k] & Reserve Fleet [FR] & Interval [FR] \\
\hline \hline 5 & 115 & 2 & {$[2,3]$} \\
10 & 115 & 3 & {$[3,4]$} \\
15 & 115 & 5 & {$[5,6]$} \\
20 & 115 & 6 & {$[6,7]$} \\
25 & 115 & 8 & {$[8,9]$} \\
30 & 115 & 9 & {$[9,10]$} \\
35 & 115 & 11 & {$[11,12]$} \\
40 & 115 & 13 & {$[13,14]$} \\
45 & 115 & 14 & {$[14,15]$} \\
50 & 115 & 16 & {$[16,17]$} \\
55 & 115 & 17 & {$[17,18]$} \\
60 & 115 & 19 & {$[19,20]$} \\
\hline
\end{tabular}

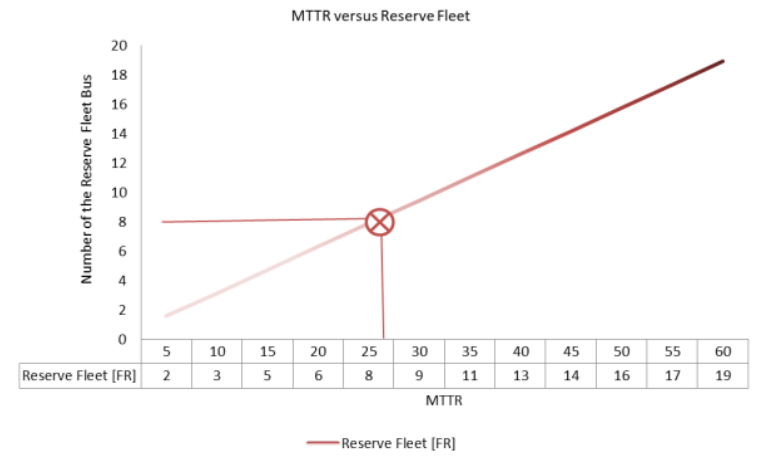

Fig. 14 - Graph of MTTR versus Reserve FleetCompany under study

From the Graph of MTTR versus Reserve Fleet can be seen that, for a real MTTR of 25 days, in a fleet of 115 buses, a value of 8 units is obtained for the size of the reserve fleet.

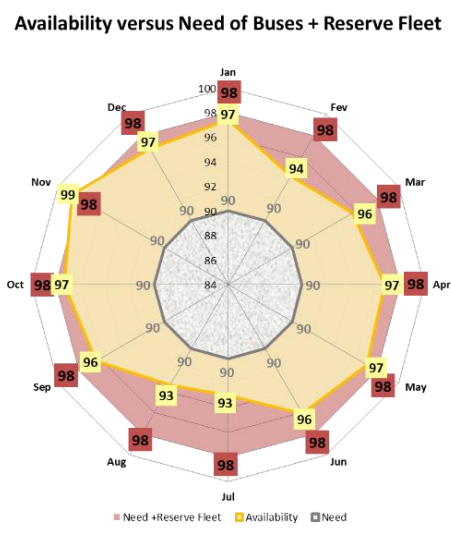

Fig. 15 - Radar map of the Availability versus necessity + Reserve Fleet

Through this model, calculations can be carried out to obtain the size of the reserve fleet for other companies of larger or smaller size, taking into account the number of buses that make up their fleets and the MTTR reliability indicator as presented will be presented next.

Table 8-Bus Fleet versus Reserve Fleet

\begin{tabular}{c|c|c|c} 
MTTR [days] & Bus Fleet [k] & Reserve Fleet [FR] & Interval [FR] \\
\hline \hline 25 & 100 & 7 & {$[7,8]$} \\
25 & 500 & 34 & {$[34,35]$} \\
25 & 1000 & 68 & {$[68,69]$} \\
25 & 1500 & 103 & {$[103,104]$} \\
25 & 2000 & 137 & {$[137,138]$} \\
25 & 2500 & 171 & {$[171,172]$} \\
25 & 3000 & 205 & {$[205,206]$} \\
25 & 3500 & 240 & {$[240,241]$} \\
25 & 4000 & 274 & {$[274,275]$} \\
\hline
\end{tabular}




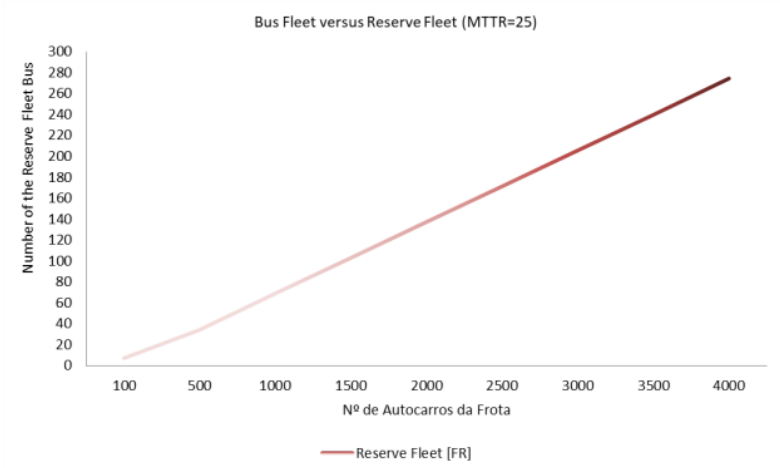

Fig. 16-Graph of the Bus Fleet versus Reserve Fleet

Table 8 and Figure 16 show the size of the reserve fleet for several passenger transport companies, considering a constant value of 25 days for the MTTR, varying the size of the bus fleet and, consequently, this value related to the size of the company. Thus, the various values of the number of buses in the reserve fleet can be obtained depending on the size of the organization.

\section{Results}

The various approaches carried out throughout the paper, aiming at replacing buses and assessing the size of the reserve fleet, gave rise to the creation of a new integrated management model, which was called Model Integrated Reserve Fleet Assessment (MIRFA), as was illustrated in Figure 5, and that summarizes the global approach that was underlying the present paper.

The preceding approaches constitute a single model of analysis that allows determining the most rational period for replacing buses and, consequently, the reserve fleet, given that the first implies the second. It should be noted that the previous integrated approach is valid for new and used buses, considering the effect of monetary correction. Obviously, technological and environmental aspects are excluded from this analysis.

\section{Conclusions}

The paper focuses on economic models for determining the most rational moment for replacing buses in transport companies, indexed to the size of the reserve fleet. The overall result is centred on an integrating model to support the replacement of urban transport buses, but with the potential to extend to other types of equipment.

The main objectives of the research carried out were as follows: Rationalize the equipment / bus life cycle management; Streamline the time for replacing equipment / buses; Streamline the reserve fleet.
The economic aspects were guided by different indicators, such as the costs associated with the acquisition, maintenance, operation, cash flow, among others.

The paper was based on classic tools for determining the most rational time for replacing equipment but taking as reference the maintenance policies and their relationship with the Life Cycle Cost (LCC), applied to real data from an urban public transport company.

The paper also demonstrates that there is a variation in the more rational vehicle's replacement time, obtained by the several calculation methods used, namely, the Uniform Annual Income method, the Minimization of the Total Average Cost and the Minimization of the Total Average Cost with reduction to the present value.

It also demonstrates the influence of endogenous and exogenous variables, namely the rate of inflation, capitalization, the replacement value and the price of Diesel in determining the most rational moment for replacing buses.

Another aspect emphasized in the paper is related to the conditioning / predictive maintenance policies, given that they may be responsible for reducing the company's general expenses and increasing the operational availability of the equipment. This aspect is supported through the case of oil analysis, demonstrating that, the use of a conditioning / predictive maintenance policy influences the LCC and the size of the reserve fleet.

In this regard, some variables stand out, such as Soot, Viscosity and Iron content, which give relevant indications about the condition of Diesel engines. This same analysis can be extended to the remaining variables that allow the characterization of lubricating oils.

The paper also presents the relationship between the previous approach and the size of the reserve fleet in the urban passenger transport sector, demonstrating the relationship that exists between oil replacement intervals and the respective costs.

Finally, an integrating model of the preceding methodologies is presented in a global econometric model to support the decision to replace buses and calculate the size of the reserve fleet, which was called the Integrated Reserve Fleet Assessment Model (MIAFRA). In addition, it validates these methodologies using real data from a fleet of urban passenger buses.

The preceding approaches constitute a single model of analysis that allows determining the most rational period for replacing buses and, consequently, the reserve fleet, given that the first implies the second. It should be noted that the previous integrated approach is valid for new and used buses, taking into account the effect of monetary correction. 


\section{References}

[1] Alsyouf, I. (2006): Measuring maintenance performance using a balanced scorecard approach. Journal of Quality in Maintenance Engineering, Volume 12 Issue: 2, pp.133 - 149. http://dx.doi.org/10.1108/13552510610667165

[2] Amaral, F. D. (2016): Gestão da Manutenção na Indústria. Lisboa: $1^{\mathrm{a}}$ Edição, Lidel - Edições Técnicas Lda. ISBN 978-989-752-151-5.

[3] Amaya, E. J.; Tonaco, R.;Souza, R. Q.; Álvares, A. J. (2007): Sistema Inteligente de Manutenção Baseada em Condição para Usina Hidreléctrica de Balbina. Universidade de Brasília, Departamento de Engenharia Mecânica e Mecatrónica, Grupo de Inovação em Automação Industrial (GIAI), CEP 70910-900, $8^{\text {th }}$ Congresso Engenharia Mecânica, Ibero-Americano, Brasília, DF, Brazil.

[4] André, J. C. S. (2008): Ensinar e Estudar Matemática em Engenharia. Lisboa: $1^{a}$ Edição, Imprensa da Universidade de Coimbra. ISBN 978989-8074-37-9.

DOI:

http://dx.doi.org/10.14195/978-989-26-0354-4.

[5] André, J. C. S. (2008): Probabilidades $e$ Estatística para Engenharia. Lisboa: $1^{\text {a }}$ Edição, Lidel - Edições Técnicas Lda. ISBN 978-972-757477-3.

[6] Aoudia, M.; Belmokhtar, O. (2008): Economic impact of maintenance management ineffectiveness of na oil gas company. Journal of Quality in Maintenance Engineering, Volume 14, Issue 3, pp. 237-261.

[7] Araujo, M. S.; Bezerra, C. A. (2004): Development of components for stochastic systems for decision support. PUCPR Brazilian, Congress of Computer Science, Software Engineering, Brazil, pp 101-107.

[8] Assaf Neto, A. (2005): Finanças corporativas e valor. São Paulo: Atlas. ISBN: 9788522460144.

[9] Assis R.; Julião, J. (2009): Gestão da Manutenção ou Gestão de Activos? (custos ao longo do Ciclo de Vida). Comunicação $10^{\circ}$ Congresso Nacional Manutenção, APMI, Figueira da Foz, Portugal.

[10] Assis, R. (2010): Apoio à decisão em manutenção na gestão de activos fisicos. Lisboa: $1^{\mathrm{a}}$ Edição, Lidel - Edições técnicas, Lda.ISBN: 9789897521126.

[11] ASTM International (2002): Standard practice for measuring life-cycle costs of buildings and building system. Annual Book of ASTM Standards: 2002, Volume 4, ASTM International West Conshohocken, PA, E 917, No. 11.
[12] BAS PAS 55 (2008): Asset Management: PAS 55-1, Part 1: Specification for the optimized management of physical assets | PAS 55-2, Part 2: Guidelines for the application of PAS 55-1. British Standards, UK.

[13] Beichelt F. (2001): A replacement policy based on limiting the cumulative maintenance cost. Department of Statistics and Acturial Science, University of Witwatersrand, Johannesburg, South Africa; International Journal of Quality \& Reliability Management, . MCB University Press, 0265-671X, Volume. 18 No. 1, pp. 76-83.

[14] Bescherer, F. (2005): Established Life Cycle Concepts in the Business Environment Introduction and terminology, Laboratory of Industrial Management Report Series, report 1/2005, Helsinki University. ISBN 951-22-7549.

[15] Bourne, M. (2005): Researching performance measurement system implementation: the dynamics of success and failure. Production Planning \& Control, Volume 16, Issue: 2, pp. 101-113.

[16] Bourne, M., Neely, A., Platts, K., Mills, J. (2002): The success and failure of performance measurement initiatives Perceptions of participating managers. International Journal of Operations \& Production Management, Volume 22, Issue: 11, pp. 1288-1310.

[17] Brown, M. (2003): Applying the Predictive Approach. Copyright 2003 New Standard Institute, Inc. www.newstandardinstitute.com, nsi@newstandardinstitute.com,

https://www.maintenance.org/fileSendAction/fcTyp e/0/fcOid/399590942963971199/filePointer/399590 942964810189/fodoid/399590942964810187/Appl ying_the_Predictive_Approach.pdf

[18] Cabral, J. P. S. (2009): Gestão da Manutenção de equipamentos, instalações e edifícios. LIDEL, Biblioteca Industria \& Serviços.

[19] Cabral, J. S (2006): Organização e Gestão da Manutenção. Lisboa: $6^{\text {a }}$ Edição, Lidel - Edições Técnicas Lda. ISBN: 9789727574407.

[20] Cabrita, C. P., Cardoso, A. J. M. (2013): Concepts and definitions of failure and breakdown in the Portuguese maintenance standards NP EN 13306: 2007 and NP EN 15341: 2009. CISE Electromechatronic Systems Research Centre, University of Beira Interior, 17 Ibero-American Congress on Maintenance, Cascais, Portugal.

[21] Campello, R. J. G. B.; Amaral, W. C. (2001): Modelling And Linguistic Knowledge Extration From Systems Using Fuzzy Relation Models. Fuzzy Sets and Systems, Volume n. 121, pp. 113-126. 
[22] Campos, L. C. D.; Vellasco, M. M. B. R.; Lazo, J. G. L. (2010): Um modelo estocástico baseado em redes neurais. Tese de doutoramento (Ph.D.), UFJF, Juiz de Fora, Brazil.

[23] Casarotto F., N. (2000): Análise de investimentos - matemática financeira, engenharia económica, tomada de decisão, estratégia empresarial. \&ndash; 9.ed. \&mdash; São Paulo: Atlas. ISBN: 85-224-2572-8.

[24] Chena, D.; Wanga, L.; Li, L. (2015): Position computation models for high-speed train based on supportvector machine approach. Control and Safety, Beijing Jiaotong University, Beijing 100044, China,

http://dx.doi.org/10.1016/j.asoc.2015.01.017.

[25] Clifton, R. H., (1985): Principles of planned maintenance. London, Edward Arnold (Publishers), Ltd. ISBN: 0713133171: 0713133171.

[26] Costa A. H. P. (2008): Transportes Públicos. Manual do Planeamento de Acessibilidades e Transportes, Universidade do Porto e Comissão de Coordenação e Desenvolvimento Regional do Norte.

[27] Couellan, N.; Jana, S.; Jorquera T.; George J.P. (2015): Self-adaptive Support Vector Machine: A multi-agent optimization perspective. Université de Toulouse, UPS IMT, F-31062 Toulouse Cedex 9, France,

http://dx.doi.org/10.1016/j.eswa.2015.01.028.

[28] Di, J.; Hauke, L. (2000): Optimal fleet utilization and replacement. Transportation Research Part E, Volume 36, Issue 1, pp. 3-30. ISSN: 1366-5545.

[29] Durairaj, S.K., et al. (2002): Evaluation of life cycle cost analysis methodologies. Corporate Environment Strategy, Volume 9, Issue 1, pp. 30-9.

[30] Emblemsvag, J. (2001): Activity-based lifecycle costing. Managerial Auditing Journal, Volume 16, Issue 1, pp. 17-27.

[31] Farinha, J. M. T., (1997): Manutenção de Instalações e Equipamentos Hospitalares - Uma Abordagem Terológica. Livraria Minerva Editora, Coimbra, Portugal. ISBN: 9728318162.

[32] Farinha, J. M. T. (2011): Manutenção - A Terologia e as Novas Ferramentas de Gestão. Lisboa: $1^{\text {a }}$ Edição, Monitor - Projecto e Edições, Lda. ISBN 978-972-9413-82-7.

[33] Farinha, J. M. T. (2018): “Asset Maintenance Engineering Methodologies". CRC Press; 1 edition (May 29, 2018). English. Printed in USA. ISBN-10: 1138035890. ISBN-13: 978-1138035898
[34] Feldens, A. G.; Muller, C. J.; Filomena, T. P.; Neto, F. J. K.; Castro, A. S.; Anzanello, M. J. (2010): Política para Avaliação e Substituição de Frota por Meio da Adoção de Modelo Multicritério. Porto Alegre, Brazil, ISSN 1980-4814.

[35] Ferreira, L. A., (1998). Uma Introdução à Manutenção. Publindústria, Edições Técnicas, Porto - Portugal. ISBN 972-95794-4-X.

[36] Ferreira, L. A. (2013): Conferência-Gestão de Activos Físicos. Ordem dos Engenheiros.

[37] Ferreira, L., Silva, (2002). A Importância de Atingir Niveis Elevados de Disponibilidade e Segurança em Sistemas Complexos. Comunicação ao $1^{\circ}$ Congresso Mundial de Manutenção, SalvadorBahia, Brasil.

[38] Figueiredo, L. M. J. (2009): Modelo multicritério de apoio à substituição de equipamentos médicos hospitalares. Tese de doutoramento (Ph.D.), IST, Lisboa, Portugal.

[39] Francis, K. N.; Leung and Ada; Cheng, L.M. (2000): Determining replacement policies for bus engines. City University of Hong Kong, Hong Kong; International Journal of Quality \& Reliability Management, MCB University Press, 0265-671X, Volume 17 No. 7, pp. 771-783.

[40] Guerrero, J. M; Castilla, A. E.; SánchezFernández, J. Á; Platero, C. A. (2020): Fluid Degradation Measurement Based on a Dual Coil Frequency Response Analysi. Sensors 2020, 20, 4155; $\quad$ www.mdpi.com/journal/sensors; doi:10.3390/s20154155.

[41] Gits, C. W. (1994): Structuring Maintenance control Systems. International Journal of Operations $\&$ Production Management, Volume 14, Issue: 7, pp. 5-17.

[42] Grall, A., Bérenguer C., Dieulle, L. (2001): $A$ Condition-Based Maintenance Policy for Stochastically Deteriorating Systems. Reliability Engineering \& System Safety, Elsevier Science, Université de Technologie de Troyes, Volume 76, Issue 2, pp 167-180.

[43] Gurney, K. (1997): An introduction to neural networks. London, UCL Press. ISBN: 1857285034.

[44] Huang, Jia-Yen, Yao, Ming-Jong (2008): On the coordination of maintenance scheduling for transportation fleets of many branches of a logistic service provider. Ling Tung Universityl Ling Tung Road, Nantun, Taichung 408, Taiwan, ROC. doi:10.1016/j.camwa.2008.01.037

[45] Husband, T. M., (1988): Maintenance Management and Terotechnology. Westmead: Saxon House. ISBN: 0566001462. 
[46] ISO 55000:2014 (2014) - Asset management Overview, principles and terminology; ISO 55001:2014 - Asset management - Management systems - Requirements; ISO 55002:2014 - Asset management - Management systems - Guidelines for the application of ISO 55001.

[47] Khasnabis, S.; Alsaidi, E.; Ellis, R. (2002): Optimal allocation of resources to meet transit fleet requirements. Journal of Transportation Engineering, Volume 128, Issue 6, pp. 509-518.

[48] Korpi, E. and Ala-Risku, T. (2008): Life cycle costing: a review of public case studies. Managerial Auditing Journal, Volume 23, Issue 3, pp. 240-61.

[49] Kumar, U. (2006): Development and implementation of maintenance performance measurement system: issues and challenges. Proceedings of the First World Congress on Engineering Asset Management, Springer, 2006. p. 738-743.

[50] Kumar, U., Galar, D., Parida, A., Stenström, C., Berges, L. (2013): Maintenance performance metrics: a state- of-the-art review. Journal of Quality in Maintenance Engineering, Volume 19, Issue: 3, pp.233-277, https://doi.org/10.1108/JQME05-2013-0029.

[51] l'Association Française de Normalisation (AFNOR), (2002): "FD X 60-000 -Normalisation Française - Maintenance industrielle Fonction maintenance", Françe.

[52] Levitt, J., (2002): Complete Guide to Preventive and Predictive Maintenance. Industrial Press, Inc. ISBN-10: 083113352X. ISBN-13: 978-0831133528.

[53] Lima, W. C., Sales, J. A. A. (2008): Manutenção Preditiva Caminho para a Excelência e Vantagem Competitiva.

[54] Lindholm, A. and Suomala, P (2004): The possibilities of Life Cycle Costing in Outsourcing Decision Making. Frontiers of E-Business Research, pp.226-241.

[55] Luna, I., Ballini, R., and Soares, S. (2006): Identification technique of linear and nonlinear time series. Magazine Automation and Control, Volume 17, Issue 3, pp. 245-256.

[56] Macián V., Tormos B, Bastidas S, Pérez T. (2020): Improved fleet operation and maintenance through the use of low viscosity engine oils: fuel economy and oil performance. Eksploatacja i Niezawodnosc - Maintenance and Reliability; 22 (2): 201-211,

http://dx.doi.org/10.17531/ein.2020.2.3.

[57] Macián, V., Tormos, B., Miro G., Pérez T. (2015): Assessment of low-viscosity oil performance and degradation in a heavy duty engine real-world fleet test. Proc IMechE Part J: Journal Engineering Tribology, Volume 0, Issue: 0, pp. 1-15. DOI: 10.1177/1350650115619612.

[58] Macián, V., Tormos, B., Ruiz, S., Ramirez L. (2015): Potential of low viscosity oils to reduce CO2 emissions and fuel consumption of urban buses fleets. Transportation Research Part D, Volume 39, pp.76-88.

http://dx.doi.org/10.1016/j.trd.2015.06.006.

[59] Macián, V., Tormos, B., Ruiz, S., Ramirez R., L. et al. (2014): In-Use Comparison Test to Evaluate the Effect of Low Viscosity Oils on Fuel Consumption of Diesel and CNG Public Buses. SAE Technical Paper 2014-01-2794. doi:10.4271/201401-2794.

[60] Macián, V.; B Tormos; Gomez Estrada, YA.; Bermúdez, V. (2013). Revisión del proceso de la degradación en los aceites lubricantes en motores de gas natural comprimido y diesel. Dyna Ingeniería e Industria, Volume 88, Issue: 1, pp.49-58. doi:10.6036/5077.

[61] Makridakis, S.; Wheelwright, S. \& Hyndman, R. F. (1998): Forecasting -Methods and Applications. New York: John Wiley \& Sons. ISBN 0-471-53233-9.

[62] Marco, A. R.; Angelo, A. D.; Leizer, S.; Silvio, A. B. V. (2010): The use of Bayesian networks in the decision making process interventions in equipment. Industrial Engineering Program, Federal University of Bahia, Polytechnic School, XVIII Brazilian Congress Auto / 12 to 16 September 2010 Federation, 40210-630, Salvador, Brazil, pp. 50585064.

[63] Martorell, S., Sanchez, A., Muñoz, A., Pitarch, J. L., Serradell, V., Roldan, J. (1999): The use of maintenance indicators to evaluate the effects of maintenance programs on Npp performance and safety. Reliability engineering \& System safety, Volume 65, pp. 85-94.

[64] Mather, D. (2005): The Maintenance Scorecard - Creating Strategic Advantage. $1^{\text {st }}$ Ed. Industrial Press, New York, NY.

[65] Mirshawka, V., Olmedo, N. (1993): Manutenção - Combate aos Custos da NãoEficácia: A vez do Brasil. Editora Makron Books, São Paulo, Brasil.

[66] Mobley, R. K., (2002): An Introduction to Predictive Maintenance. Butterworth-Heinemann Elsevier, USA. ISBN 0-7506-7531-4.

[67] Motta, R. R.; Calôba, G. M. (2002): Análise de investimentos: tomada de decisão em projetos 
industriais. São Paulo: Atlas. ISBN: 9788522430796.

[68] Moubray, J. (2000): Manutenção Centrada em Confiabilidade. Aladon Ltda, São Paulo, Brasil.

[69] Moubray, J., (2004): Reliability-Centered Maintenance. Second Edition, Industrial Press, Inc.

[70] Muchiri, P., Pintelon, L., Gelders, L., Martin, H., (2011): Development of maintenance function performance measurement framework and indicators. International Journal of Production Economics, Volume 131 Issue: 1, pp. 295-302. doi:10.1016/j.ijpe.2010.04.039.

[71] Múller, D. (2007): Stochastic processes and applications. Collection Economic Volume 2 Series off Financial Law and Tax. Almedina.

[72] Mutingi M., Nangolo V., Musiyarira H., Mbohwa C. (2016): Adoption of Maintenance Key Performance Indicators in the Nambian Mining Industry. Proceedings of the World Congress on Engineering and Computer Science 2016 Volume II WCECS, October 19-21, 2016, San Francisco, USA. ISBN: 978-988-14048-2-4; ISSN: 2078-0958 (Print); ISSN: 2078-0966 (Online).

[73] Natali, H.; Yuri Y. (2007): Optimal equipment replacement without paradoxes: A continuous analysis. Operations Research Letters. ELSEVIER. Volume 35, Issue 2, March, pp. 245-250.

[74] NP EN 13306:2007, (2007): Terminologia da Manutenção. Instituto Português da Qualidade (IPQ).

[75] NP EN 15341:2009, (2009): Manutenção Indicadores de desempenho da manutenção (KPI). Instituto Português da Qualidade (IPQ).

[76] Oliveira, J. A. N. (1982): Engenharia Económica - Uma abordagem às Decisões de Investimento. São Paulo: McGraw-Hill Brazil.

[77] Otani, M., Machado, W. V. (2008): A proposta de desenvolvimento de gestão da manutenção industrial na busca da excelência ou classe mundial. Revista Gestão Industrial, Volume 4, Issue: 2, pp.0116. ISSN 1808-0448.

[78] Pais, E., Farinha, J.T., Raposo, H. (2020): ISO 55001 - A PRAGMATIC PROPOSAL FOR DIAGNOSIS AND IMPLEMENTATION. Proceedings IRF2020: 7th International Conference Integrity-Reliability-Failure. J.F. Silva [79] Gomes and S.A. Meguid (editors), INEGI-FEUP (2020), Paper Ref: 17210: 739-742. https://paginas.fe.up.pt/ irf/Proceedings_IRF2020/

[79] Pais, E.; Raposo, Hugo D. N.; Ana Meireles; Farinha, J. M. T. (2019): ISO 55001 - A Strategic
Tool for the Circular Economy - Diagnosis of the Organization's State. Journal of Industrial Engineering and Management Science 2019 (1): 89$108 . \quad \mathrm{https} / / /$ doi.org/10.13052/jiems24461822.2018.005.

[80] Pais, E., Raposo, H., Meireles, A., \& Farinha, J. T. (2018): ISO 55001 - A strategic tool for the Circular Economy - Diagnosis of the Organization's State. Procedings of Maintenance, Performance, Measurement and Management Conference. (MPMM 2018). Coimbra, Portugal.

[81] Parida, A. (2007): Study and analysis of maintenance performance indicators (MPIs) for LKAB: A case study. Journal of Quality in Maintenance Engineering, Volume 13, Issue: 4, pp. 325-337. doi:10.1108/13552510710829434.

[82] Parida, A., Chattopadhyay, G. (2007): Development of a multi-criteria hierarchical framework for maintenance performance measurement (MPM). Journal of Quality in Maintenance engineering, Volume 13, Issue: 3, pp. 241-258.

[83] Parida, A., Kumar U., (2006): Maintenance performance measurement (MPM), issues and challenges. Journal of Quality in Maintenance Engineering, Volume 12 Issue: 3, pp.239 - 251. http://dx.doi.org/10.1108/13552510610685084.

[84] Pinar, K.; Hartman, J. (2004): Case Study: Bus Fleet Replacement. The Engineering Economist, Volume 49, Issue 3, pp. 253-278.

[85] Pinto, C. V. (2002): Organização e Gestão da Manutenção. Lisboa: $2^{\mathrm{a}}$ Edição, Monitor - Projecto e Edições, Lda.

[86] Pooyan N., Shahbazian M., Salahshoor K.; Hadian M. (2015): Simultaneous Fault Diagnosis using multi class support vector machine in a Dew Point process. Department of Instrumentation and Automation, Petroleum University of Technology, Ahwaz, http://dx.doi.org/10.1016/j.jngse.2015.01.043.

[87] Raposo H. D. N., Farinha, J. T., Ferreira, L. (2013): Transporte público de passageiros - A importância da condição dos óleos na qualidade do serviço. Revista Manutenção / $3^{\circ}$ trimestre, Grupo Publindústria, Volume 117, pp. 4-11.

[88] Raposo H. D. N.; Farinha, J. T.; Oliveira, R.; Ferreira, L. A.; André, J. (2014): Time Replacement Optimization Models for Urban Transportation Buses with Indexation to Fleet Reserve. MPMM Maintenance Performance Measurement and Management; Coimbra, Portugal. ISBN 978-9728954-43-7; http://dx.doi.org/10.14195/978-9728954-42-2_7. 
[89] Raposo H. D. N.; Farinha, J. T.; Luís Andrade Ferreira; Galar, D. (2017): An integrated econometric model for bus replacement and determination of reserve fleet size based on predictive maintenance. Journal Maintenance and Reliability 19 (3): 358-368. http://dx.doi. org/10.17531/ein.2017.3.6. URN: urn:nbn:se:ltu:diva-64691; DOI: 10.17531/ein.2017.3.6; ISI: 000403344800006; Scopus ID: 2-s2.0-85020500047; OAI: oai:DiVA.org:Itu-64691; DiVA, id: diva2:1118355.

[90] Raposo, H., Meireles, A., Pais, E., \& Farinha, J. T. (2017): Análise de Investimento versus Análise do Ciclo de Vida no Contexto das ISO $55000 \mathrm{com}$ ênfase na Gestão de Manutenção. 14. ${ }^{\circ}$ Congresso Nacional de Manutenção. Maia, Portugal.

[91] Raposo H. D. N.; Farinha, J. T.; Inácio Fonseca. (2018): CONDITION MONITORING WITH PREDICTION BASED ON OIL ENGINES OF URBAN BUSES - A CASE STUDY. Proceedings IRF2018: 6th International Conference IntegrityReliability-Failure, Lisbon/Portugal 22-26 July 2018. Editors J.F. Silva Gomes and S.A. Meguid, Publ. INEGI/FEUP (2018); Paper Ref: 7070: 751754. ISBN: 978-989-20-8313-1. https://paginas.fe.up.pt/ irf/Proceedings_IRF2018/d ata/papers/7070.pdf.

[92] Raposo H. D. N.; Farinha, J. T.; Luís Andrade Ferreira; Galar, D. (2018): Dimensioning Reserve Bus Fleet using Life Cycle Cost Models and Condition Based / Predictive Maintenance - a Case Study. Journal Public Transport 10 (1): 1-22. https://doi.org/10.1007/s12469-017-0167-x.

[93] Raposo H. D. N.; Farinha, J. T.; Fonseca, Inácio; Galar, D. (2019): Predicting condition based on oil analysis - A case study. Tribology International 135: 65-74. http://dx.doi.org/10.1016/j.triboint.2019.01.041.

[94] Raposo H. D. N.; Farinha, J. T.; Fonseca, I. (2019): Condition Monitoring with Prediction Based on Diesel Engine Oil Analysis: A Case Study for Urban Buses. MDPI, Actuators 8 (1): 1-14. http://dx.doi.org/10.3390/act8010014.

[95] Raposo H. D. N.; Farinha, J. T.; Luís Andrade Ferreira; Didelet, F. (2019): Economic life cycle of the bus fleet: a case study. International Journal of Heavy Vehicle Systems 26 (1): 31-54. https://doi.org/10.1504/IJHVS.2019.097109.

[96] Raposo H. D. N.; Farinha, J. T.; Inácio Adelino da Fonseca; Galar, D. (2019): Economic Life Cycle versus Lifespan - A Case Study of an Urban Bus Fleet. Engineering and Applied Sciences 4 (2): 3043. http://dx.doi.org/10.11648/j.eas.20190402.12.
[97] Raposo H. D. N.; Farinha, J. T.; Luís Andrade Ferreira; Galar, D. (2019): Reserve Fleet, Indexed to Exogenous Cost Variables. Transport. 34 (4): 437 454. https://doi.org/10.3846/transport.2019.11079. https://hdl.handle.net/10216/125217.

[98] Sanchesa, A. M.; Louresa, E. F. R.; Lima, E. P (2019): Use of PROMETHEE Method for Decision Making in Bus Fleet Maintenance Proposal of Framework. 25th International Conference on Production Research Manufacturing Innovation: Cyber Physical Manufacturing, August 9-14, 2019 | Chicago, Illinois (USA), Procedia Manufacturing, Volume 39, pp. 1913-1920.

[99] Scarf, P. A.; Bouamra, O. A. (1999): Capital equipment replacement model for a fleet with variable size. Centre for OR and Applied Statistics, University of Salford, UK, Journal of Quality in Maintenance Engineering, (C) MCB University Press, 1355-251Volume 5 No. 1, pp. 40-49.

[100] Seabra, J.; Graça, B. (1996): Analysis of oils and greases in service. Proceedings of the Fifth National Congress of Industrial Maintenance APMI, Figueira da Foz.

[101] Simões, A. S. (2011): Manutenção Condicionada às Emissões Poluentes em Autocarros Urbanos - Diagnóstico por Cadeias Escondidas de Markov. Tese de doutoramento (Ph.D.), Instituto Superior Técnico.

[102] Slack, N., \& Lewis, M. (2008): Operations strategy $\left(2^{a}\right.$ ed.). London: Prentice-Hall Financial Times.

[103] Souza, F. (2002): Decisões racionais em situações de incerteza. Recife: Ed. Universitária da UFPE.

[104] Souza, V. C. (2011): Organização e Gerenciamento da Manutenção: Programa e Controle de Manutenção, 4a Edição, All Printe Editora, São Paulo.

[105] Stenström, C., Parida, A., Kumar, U., Galar, D. (2013): Performance indicators and terminology for value driven maintenance. Journal of Quality in Maintenance Engineering, Volume 19, Issue: 3, pp.222-232, https://doi.org/10.1108/JQME-052013-0024

[106] Tsoukalas, L. H.; Uhrig, R. E. (1996): Fuzzy and neural approaches in engineering. New York: John Wiley. ISBN: 0471160032.

[107] Vey, I. H.; Rosa, R. M. (2004): Fleet replacement in municipal passenger transportation company: a case study. Federal University of Santa Maria, Electronic Accounting Journal, Volume 1, Issue 1, Sep-Nov, pp. 150-173. 
[108] Visser, J., Kotze, R. L. M. (2010): Maintenance performance indicators: An analysis in the mining industry, pp. 1-32.

[109] Vujanovic, D.; Momc ilovic, V.; Bojovic, N.; Papic, V. (2012): Evaluation of vehicle fleet maintenance management indicators by application of DEMATEL and ANP. University of Belgrade, Faculty of Transport and Traffic Engineering, Vojvode Stepe 305, Belgrade, Serbia. http://dx.doi.org/10.1016/j.eswa.2012.02.159.

[110] Weber, A., Thomas, R. (2005): Key Performance Measuring and Managing the Maintenance. Burlington Ontario.

[111] Wijaya, A. R.; Lundberg, J.; Kumar, U. (2012): Robust-optimum multi-attribute age-based replacement policy. Division of Operation and Maintenance Engineering, Lulea University of Technology, Lulea, Sweden; Journal of Quality in Maintenance Engineering, Vol. 18 No. 3, 2012 pp. 325-343, Emerald Group Publishing Limited 13552511, DOI 10.1108/13552511211265910.

[112] William, G. S.; Thomas, N. M.; Eileen M. V. A. (2002): Equipment replacement decisions and lean manufacturing. ELSEVIER. Volume 18, Issues 3-4, June-August 2002, pp. 255-265.

[113] Jennifer, L. R. and Joseph C. H. (2005): Equipment replacement under continuous and discontinuous technological change. IMA Journal of Management Mathematics; Volume 16, Issue 1, pp 23-36.
[114] Wireman, T. (2005): Developing Performance Indicators for Managing Maintenance. Industrial Press, Inc., New York.

[115] Yager, R. R. and Zadeh, L. A., ed. (1992): Introduction to fuzzy logic applications. An in intelligent systems Boston, Kluwer Academic, Publishers. ISBN 0792391918.

[116] Zahra Mahmoodzadeh; Keo-Yuan Wu; Enrique Lopez Droguett; Ali Mosleh (2020): Condition-Based Maintenance with Reinforcement Learning for Dry Gas Pipeline Subject to Internal Corrosion. Preprint · January 2020, DOI: 10.13140/RG.2.2.30350.10563, https://www.researchgate.net/publication/33871937 3.

[117] Zhao, H. (2009): A chaotic time series prediction based on neural network: Evidence from the shanghai composite index in china. In Test and Measurement, 2009. ICTM 09. International Conference on, Volume 2, pp. $382-385$.

[118] Zohrul Kabir, A. B. M. (1996): Evaluation of overhaul/replacement policy for a fleet of buses. King Saud University, Riyadh, Saudi Arabia; Journal of Quality in Maintenance Engineering, (C) MCB University Press, 1355-2511, Volume 2, Issue 3, 1996, pp. 49-59.

\section{Creative Commons Attribution License 4.0 (Attribution 4.0 International, CC BY 4.0)}

This article is published under the terms of the Creative Commons Attribution License 4.0

https://creativecommons.org/licenses/by/4.0/deed.en_US 